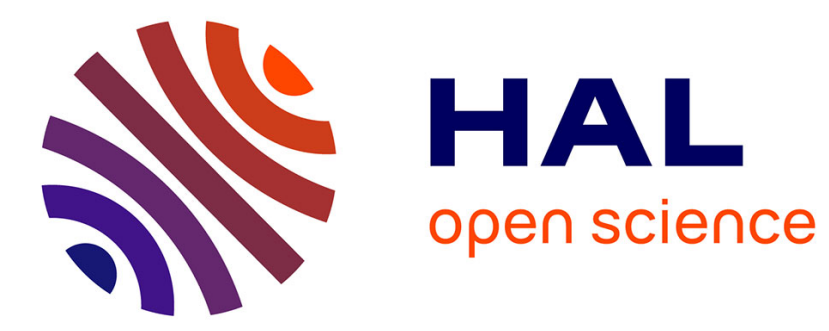

\title{
Agricultural Systems Studies using Remote Sensing
} Agnès Bégué, Damien Arvor, Camille Lelong, Elodie Vintrou, Margareth Simoes

\section{To cite this version:}

Agnès Bégué, Damien Arvor, Camille Lelong, Elodie Vintrou, Margareth Simoes. Agricultural Systems Studies using Remote Sensing. Remote Sensing Handbook, Vol.2 : Land Resources Monitoring, Modeling, and Mapping with Remote Sensing, 2015. hal-02098284

\section{HAL Id: hal-02098284 https://hal.science/hal-02098284}

Submitted on 12 Apr 2019

HAL is a multi-disciplinary open access archive for the deposit and dissemination of scientific research documents, whether they are published or not. The documents may come from teaching and research institutions in France or abroad, or from public or private research centers.
L'archive ouverte pluridisciplinaire HAL, est destinée au dépôt et à la diffusion de documents scientifiques de niveau recherche, publiés ou non, émanant des établissements d'enseignement et de recherche français ou étrangers, des laboratoires publics ou privés. 
Agricultural Systems Studies using Remote Sensing

Agnès Bégué ${ }^{1, *}$, Damien Arvor ${ }^{2}$, Camille Lelong $^{1}$, Elodie Vintrou ${ }^{1}$, and Margareth Simoes ${ }^{3}$

${ }^{1}$ CIRAD, UMR TETIS, Montpellier F-34093, France

E-Mail: agnes.begue@cirad.fr; camille.lelong@cirad.fr; elodie.vintrou@cirad.fr; Tel.: +33 4 67548754

${ }^{2}$ IRD, UMR 228 ESPACE-DEV, Montpellier F-34093, France

E-Mail: damien.arvor@ird.fr; Tel.: +334 67548754

${ }^{3}$ EMBRAPA SOLOS and PPGMA/DESC/UER - Rio de Janeiro State University, Brazil.

E-Mail: margareth.simoes@embrapa.br; Tel.: +55 2121794607

*Author to whom correspondence should be addressed: E-Mail: agnes.begue@cirad.fr

Keywords: cropping system, farming system, cropland, crop management, landscape, spatial analysis. 


\section{Introduction}

The world population is expected to reach 9.3 billion in 2050 (UN, 2010). To feed this population, the Food and Agriculture Organization last global projection exercise forecasted that the world's agricultural production will need to increase by approximately $70 \%$ by 2050 , compared with the 2005 production levels (FAO, 2011). Approximately $80 \%$ of the increased agricultural production will need to come from yield increases, and higher cropping intensities such as increased multiple cropping and/or shortening of fallow periods.

Such evolutions must cope with climate change (characterized by changing rainfall patterns and an increasing number of extreme weather events) and its consequences (changing distributions of plant and vector-borne diseases, and increased crop yield variability), more competition for land (increased competition between food and bioenergy production), and the associated increased environmental pressures (e.g., over-exploitation of ground water resources, water quality degradation, and soil degradation). As a consequence, in addition to the need to increase crop production, another major agricultural challenge is the task of improving the management of natural resources, especially through the adoption of more environmental-friendly practices, such as ecological intensification or conservation agriculture. Major agricultural powers such as Europe and Brazil have launched ambitious programs, e.g., the GAP (Good Agricultural Practice) guidelines and the ABC Program (Brazilian Low Carbon Agriculture Program), respectively. These programs give a special role to multifunctional landscapes to establish sustainable agriculture. Landscapes must be considered a whole land use system at the heart of human-nature relationships that need to be efficiently managed to preserve and restore ecosystem services (DeFries and Rosenzweig, 2010), and to contribute to sustainable solutions, especially regarding food security challenges (Verburg et al., 2013). In view of these global challenges, there is an urgent need to better characterize agricultural systems at the regional and global scales, with a particular emphasis on the various pathways towards agricultural intensification. Those systems are the key to understanding land use sustainability in agricultural territories.

Although everyone agrees on the need to qualify agricultural systems at the regional scale, few examples exist in the literature. Leenhardt et al. (2010) reviewed cropping system descriptions and locations at the regional scale, and concluded that both remain highly unclear for most world regions. The FAO continental farming system maps (Dixon et al., 2001) and the U.S. Agency for International Development (USAID) Famine Early Warning Systems Network (FEWS NET) national livelihood maps for Africa (USAID, 2009) are produced at very broad scales. More detailed, the regional maps of rice areas in Southeast Asia (Bridhikitti and Overcamp, 2012) or sugarcane areas in Brazil (Adami et al., 2012) have recently been produced using remote sensing data only. But these simple approaches, based on the dominant crop type with limited consideration of land management, are insufficient to draw a complete picture of coupled human-environment systems (Verburg et al., 2009).

So, evolving from traditional remote sensing land cover mapping to land use system mapping is not straightforward and requires processing new data, implementing new methods and, above all, an enhanced integration between land science research disciplines (Verburg et al., 2009; Koschke et al., 2013). Vaclavik et al. (2013) derived a global representation of land use systems 
using land use intensity datasets, environmental conditions and socio-economic indicators. Land use intensity was derived from satellite-based land cover maps and sub-national statistics. The authors noted that the scope of the study was limited because the quality of the statistical data sets they used was geographically distributed unevenly worldwide. Kuemmerle et al. (2013) proposed a review of the current input (crop type, cropping frequency, capital and labor intensity, etc.) and output (yields and carbon stock, etc.) land intensity metrics that could be provided directly or indirectly by satellite remote sensing. They concluded that satellite-based approaches are still experimental in that domain and cannot readily be applied across large areas. Despite these issues, new opportunities are arising.

The objective of the present study is to give an overview of remote sensing-based approaches for regional mapping of agricultural systems and to illustrate the diversity of these approaches through case studies. To do this, we propose and introduce a general framework, including satellite data and land mapping approaches, to characterize agricultural systems at different scales. These approaches are illustrated by three case studies representing a wide diversity of agricultural systems across the tropical world. Based on these case studies and a literature review, the opportunities and challenges for agricultural systems mapping at regional and global scales are discussed, and further research is proposed.

\section{Roles of remote sensing in the assessment of agricultural systems}

\subsection{Diversity of the agricultural systems in the world}

To our knowledge, the most complete global agricultural map is the map produced by the Food and Alimentation Organization (FAO) and the World Bank (Dixon et al., 2001) which covers the six main regions of the developing world. This map represents 72 farming systems (Figure 1a) that were defined according to (i) the available natural resource base (water, land, climate, altitude...), (ii) the dominant pattern of farm activities and household livelihoods, including relationship to markets, and (iii) the intensity of production activities. These detailed farming systems are grouped in eight broad categories (Figure 1b; Erreur ! Source du renvoi introuvable.). It is interesting to note that seven out of the eight broad farming systems categories are based on smallholder producers (less than 2 hectare land, according to FAO). 


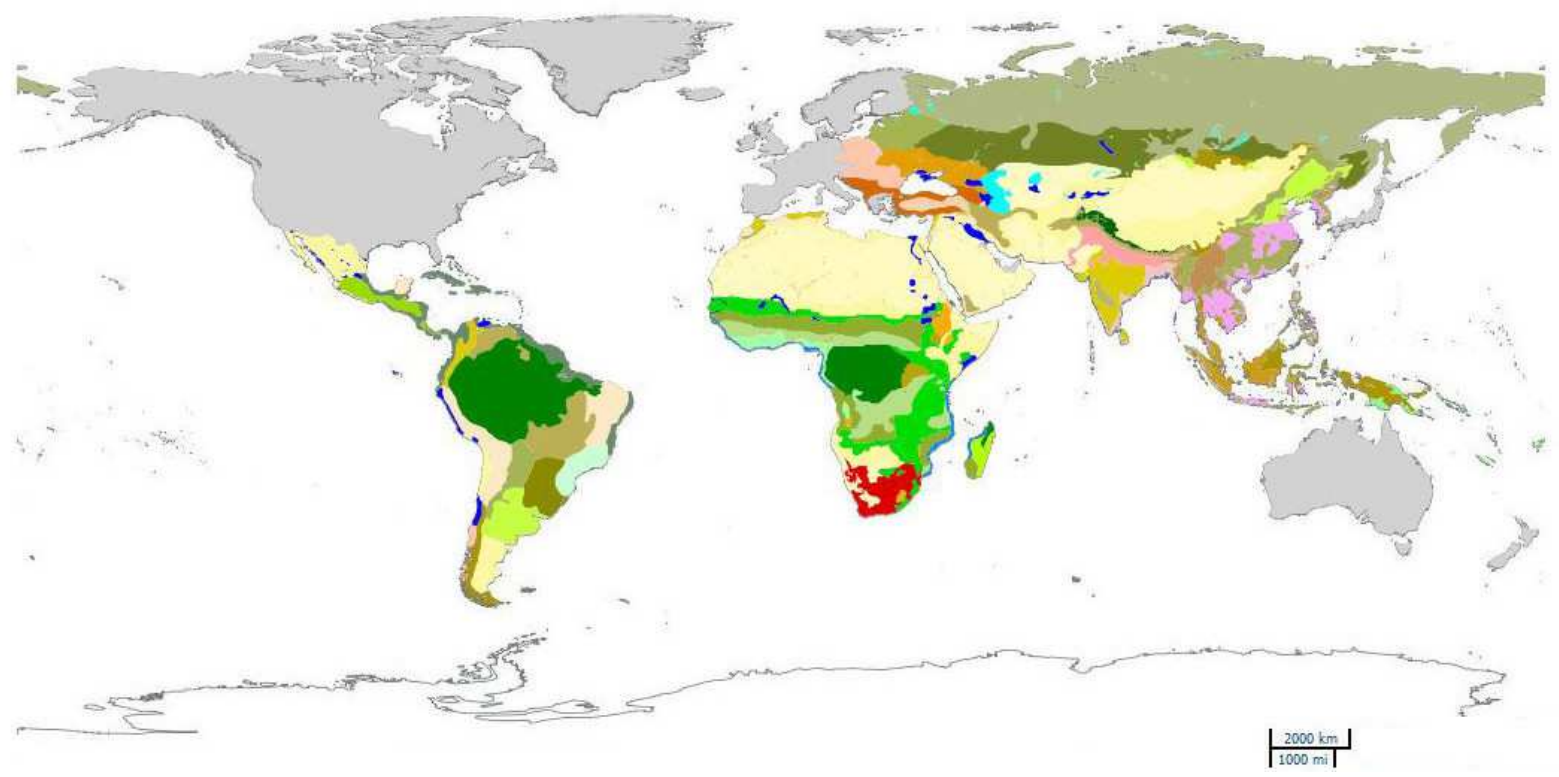

Figure 1. Farming system maps of the developing regions of the world (Dixon et al., 2001): a) the original FAO 72-class map (see Dixon et al., 2001 for legend), and b) the FAO 8-broad categories (see Erreur! Source du renvoi introuvable. for legend). Black dots in b) correspond to the location of the three case studies.

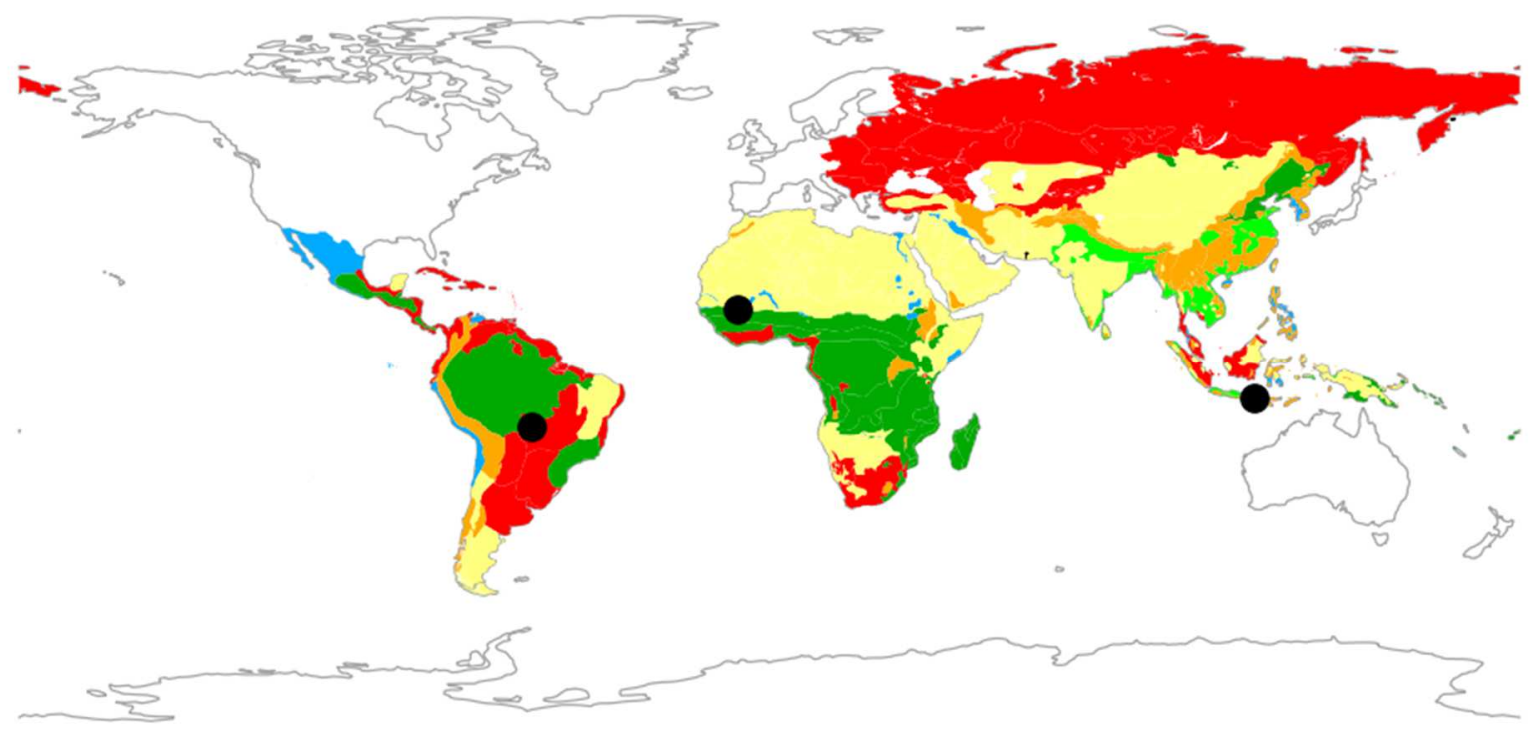

Figure 2. The conceptual framework used in this study. 
Table 1. Broad category of farming systems (Dixon et al., 2001).

\begin{tabular}{|c|c|c|}
\hline \# & Farming system name & Characteristics \\
\hline 1 & Irrigated farming systems & $\begin{array}{l}\text { Dominated by smallholder } \\
\text { producers }\end{array}$ \\
\hline 2 & Wetland rice based & $\begin{array}{l}\text { Dominated by smallholder } \\
\text { producers, dependent upon seasonal } \\
\text { rains supplemented by irrigation }\end{array}$ \\
\hline 3 & $\begin{array}{l}\text { Rainfed farming systems in humid (and } \\
\text { subhumid) areas }\end{array}$ & $\begin{array}{l}\text { Dominated by smallholder } \\
\text { producers, characterized by specific } \\
\text { dominant crops or mixed crop- } \\
\text { livestock systems }\end{array}$ \\
\hline 4 & $\begin{array}{l}\text { Rainfed farming systems in steep and } \\
\text { highland areas }\end{array}$ & $\begin{array}{l}\text { Dominated by } \begin{array}{c}\text { smallholder } \\
\text { producers, often mixed crop- } \\
\text { livestock systems }\end{array} \\
\end{array}$ \\
\hline 5 & Rainfed farming systems in dry or cold areas & $\begin{array}{l}\text { Dominated by smallholder } \\
\text { producers, with mixed crop- } \\
\text { livestock and pastoral systems } \\
\text { merging into systems with very low } \\
\text { current productivity }\end{array}$ \\
\hline 6 & Mixed large commercial and small holder & $\begin{array}{l}\text { Dualistic, across a variety of } \\
\text { ecologies and with diverse } \\
\text { production patterns }\end{array}$ \\
\hline 7 & Coastal artisanal fishing mixed & $\begin{array}{l}\text { Dominated by smallholder } \\
\text { producers, incorporates mixed } \\
\text { farming elements }\end{array}$ \\
\hline 8 & Urban based & $\begin{array}{l}\text { Dominated by } \\
\text { producers, typically }\end{array} \begin{array}{r}\text { smallholder } \\
\text { horticultural and on } \\
\text { production }\end{array}$ \\
\hline
\end{tabular}

\subsection{A conceptual framework based on land mapping issues}

Remote sensing-based information can play different roles in the assessment of agricultural systems. Figure 2 illustrates how satellite images can help derive "land maps" (land cover, land use, and land use system maps; (1) in Figure 2) using various processing approaches (2) in Figure 2). In the case of agriculture-dominated landscapes, these "land maps" can be interpreted as "agricultural system" maps (cropland, cropping system, and farming system; (3) in Figure 2). 


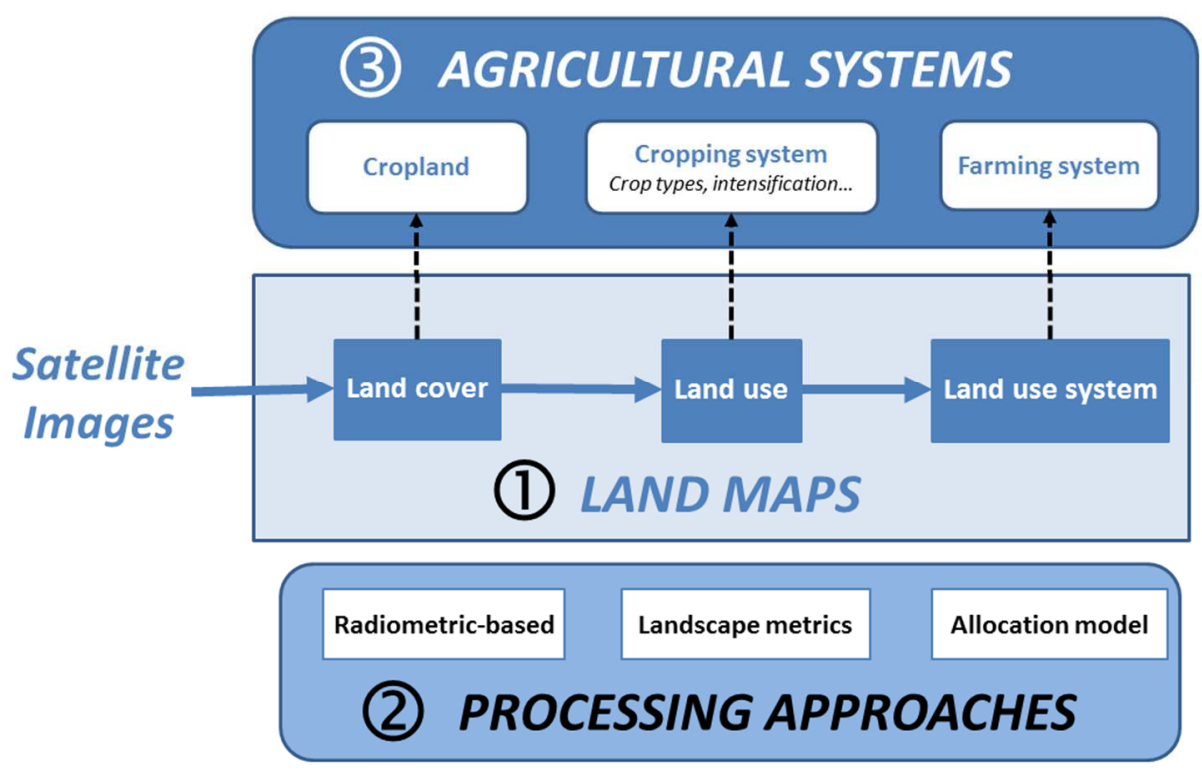

Figure 3. The conceptual framework used in this study.

Based on this framework, monitoring and mapping agricultural systems using remote sensing require clearly defined concepts and objects, i.e., which "land maps" to monitor which "agricultural systems"? In the proposed conceptual framework (Figure 2), we tried to build bridges between the land maps (land cover, land use, and land use system), that can be obtained with the contribution of remote sensing data, and the agricultural systems (cropland, cropping system, and farming system respectively) that are addressed in this chapter. These bridges are based on a set of definitions and hypotheses that are presented hereafter.

- Land cover addresses the description of the land surface in terms of soil and vegetation layers, including natural vegetation, crops, and human structures (Burley, 1961). Land use refers to the purpose for which humans exploit the land cover (Lambin et al., 2006), including land management techniques (Verburg et al., 2009). In remote sensingderived maps, mixed LULC (land use/land cover) legends are often used because concepts concerning land cover and land use activities are closely related and, in many cases, can be used interchangeably (Anderson et al., 1976). Cropping systems are defined, at least, by the dominant crop type. Crop types, or at least crop groups (e.g., winter and summer crops; Atzberger and Rembold, 2013), are often represented in these satellite-derived LULC maps. More recently, information on the intensification mode, such as the use of irrigation (e.g., Thenkabail et al., 2010) or the adoption of multiple cropping (e.g., Arvor et al., 2011), appears in the LULC maps, improving the characterization of the cropping systems using remote sensing data.

- Land use system can be defined as a coupled human-environment system. It describes how land, as an essential resource, is being used and managed by. Remote sensing data do not record human activities and thus cannot be directly used for land use system mapping. Photo-interpreters historically used patterns, tones, textures, shapes, and site 
associations to derive initial land cover information into land use information (Anderson et al., 1976). This approach is consistent with Verburg et al. (2009) who proposed obtaining land use system maps from land cover maps supplemented by observations, inferred from landscape structures. Farming systems, defined by most experts as a combination of biophysical, socio-economic and human elements of a farm, can be seen as the land use system version for agriculture.

To conclude, LCLU mapping can be obtained by classifying satellite images, while land use system mapping needs a larger view and must be approached on a larger scale (landscape scale).

\subsection{Processing approaches}

A large panel of methods and tools to produce agricultural system maps from remote sensing data are described in the literature. The methods can be grouped in three types: radiometricbased method, landscape approach and allocation models.

\section{Radiometric-based methods}

Radiometric-based methods are largely used for cropland and crop type mapping. Most of the publications report pixel or object based classifications, and photo-interpretation methods. Examples are discussed in Chapter 4, and this topic will not be further discussed in this paper.

Beyond crop type, many examples concerning remote sensing and cropping practices are found in the literature. Most of the methods are based on statistical relationships between surface variables and image variables (reflectance, spectral index, texture index, etc.), while others use signal processing techniques. The examples listed in Erreur ! Source du renvoi introuvable. show that there is a strong link between the type of cropping practice and the sensor. High resolution image primarily identifies inter- and mixed-cropping, and agroforestry composition and structure. High image acquisition frequency usually helps to identify double cropping practices, crop types or groups of crop types, and sowing/harvest dates, while spectral richness is used to distinguish cultivars. Irrigation, crop residues, and tillage practices are mainly obtained through multispectral image analyses conducted at different scales depending on the structure of the fields.

Table 2. Literature examples of use of remote sensing for mapping cropping practices. References in bold are review papers.
Cropping practice
Crop (sensor)
Example of studies 


\begin{tabular}{|c|c|c|}
\hline \multirow[t]{2}{*}{ Crop variety } & Sugarcane (Hyperion) & Galvao et al., 2005 \\
\hline & Sugarcane (Landsat) & Fortes and Dematte, 2006 \\
\hline \multirow[t]{2}{*}{ Double-cropping } & Soybean \& others (MODIS) & Arvor et al., 2011 \\
\hline & Cereals (MODIS) & Qiu et al., 2014 \\
\hline \multirow[t]{2}{*}{ Harvest date } & Sugarcane (SPOT) & Lebourgeois et al., 2007 \\
\hline & Sugarcane (SPOT) & El Hajj et al., 2007 \\
\hline Sowing date & Soybean (MODIS) & Maatoug et al., 2012 \\
\hline \multirow[t]{2}{*}{ Harvest mode } & Sugarcane (Landsat, DMC) & Aguiar et al., 2011 \\
\hline & Sugarcane (Landsat, CBERS) & Goltz et al., 2009 \\
\hline \multirow[t]{3}{*}{ Irrigation } & Various crops (MODIS) & Gumma et al., 2011 \\
\hline & Wheat (FORMOSAT, ASAR) & Hadria et al., 2009 \\
\hline & Review & Ozdogan et al., 2010 \\
\hline \multirow[t]{2}{*}{ Crop residue } & Various crops (Landsat) & Pacheco et al., 2006 \\
\hline & Review & Zhang et al., 2011 \\
\hline \multirow[t]{2}{*}{ Tillage } & Wheat (FORMOSAT, ASAR) & Hadria et al., 2009 \\
\hline & Various crops (Landsat) & Sullivan et al., 2008 \\
\hline \multirow[t]{4}{*}{ Row orientation and width } & Vineyard (aerial photos) & Delenne et al., 2008 \\
\hline & Olive groves (QuickBird) & Amoruso et al., 2009 \\
\hline & Orchards (Ikonos) & Aksoy et al., 2012 \\
\hline & $\begin{array}{l}\text { Vineyard, cereals (aerial } \\
\text { photos) }\end{array}$ & Lefebvre et al., 2011 \\
\hline
\end{tabular}

A detailed analysis of the publications on cropping practices and remote sensing shows that, even if the proportion of publications addressing this issue is increasing ( $4 \%$ of the total remote sensing and agriculture publications in the ' 90 s, and $9 \%$ currently), these publications primarily concern only one cropping practice at a time, and the analyses are generally conducted at local scale. Literature on the cropping system itself is still limited in terms of the number of publications ( $2 \%$ of the total published remote sensing and agriculture papers), and does not progress significantly.

\section{Landscape approach}

Cropland and crop type maps can be viewed as a mosaic of patches, where the patches are the landscape elements. In that case, landscape metrics can be used to characterize the agricultural 
system. The term "landscape metrics" refers to indices developed for categorical map patterns (McGarigal, 2014). Landscape metrics exist at the patch, class (patch type), and landscape level. At the class and landscape level, some of the metrics quantify the landscape composition (the relative abundance of crop patch types, for instance), while others quantify the landscape configuration (the position, connectivity or the edge-to-area ratios of the cropland, for example).

Although very few articles use landscape metrics to characterize agrosystems compared to ecosystems (see review by Uuemaa et al., 2013), some of them use crop class metrics as an input for ecological studies (e.g., Pocas et al., 2011), and a few use landscape research for agricultural perspectives. The aim of these latter is generally to evaluate different policies on agricultural landscapes or to assess the sustainability of the agricultural systems. For example, Plexida et al. (2014) discussed the role of modern cultivation methods on the simplification of landscape patterns in central Greece. They showed that the landscape in the agricultural lowlands was characterized by connectedness (high values of Patch Cohesion Index) and simple geometries (low values of fractal dimension index), whereas the landscape pattern of the pastoral uplands was found to be highly diverse (high Shannon Diversity index). Panigrahy et al. (2005) and Panigrahy et al. (2011) used landscape composition metrics to assess and evaluate the efficiency and sustainability of the agricultural systems in India. They proposed and calculated three indices, namely the Multiple Cropping Index (MCI), Area Diversity Index (ADI), and Cultivated Land Utilization Index (CLUI), using three satellite-derived seasonal land cover maps. The MCI measures the cropping intensity as the number of crops grown temporally in a particular area over a period of one year, the ADI measures the multiplicity of crops or farm products planted in a single year, and the CLUI measures how efficient the available land area has been used over the year (see Panigrahy et al., 2005) for formula). The indices were categorized as high, medium, and low to evaluate the cropping system performance in each of the districts.

An example of landscape metrics based on the spatial configuration of the classes is given in Colson et al. (2011). They used eight landscape metrics to quantify and investigate the spatial patterns of cattle pasture and cropland throughout the states of Pará, Mato Grosso, Rondônia, and Amazonas, and concluded that these metrics showed evidence of a possible measure for discerning the patterns of agriculture attached to a certain state.

\section{Spatial allocation modeling}

Global cropping system maps (crop type and irrigation) are emerging at coarse resolution (see Anderson et al. (2014) for the description and comparison of these products). They are based on statistical data downscaled at the administrative level into grid-cell specific values. An illustrative example of spatial allocation is the SPAM model (SPatial Allocation Model), developed at the meso-scale by You and Wood (2006) and You et al. (2009), to spatially disaggregate crop production data (acreage and yield) within geopolitical units (e.g., countries or sub-national provinces and districts), using a cross-entropy approach. The pixel-scale allocations are performed by compiling and merging relevant spatially-explicit data, including 
production statistics, satellite-derived land cover data, biophysical crop suitability assessments, and population density. In such models, remote sensing is mainly used to locate cropland at regional scales as an input for the allocation models (to spatially disaggregate statistics data for instance), while the crop determining factors are generally established by expertise or statistical analyses (Leenhardt et al., 2010). Recent examples showed that satellite images can also be used to understand and model the environmental drivers of cropping systems. For example, Jasinski et al. (2005) used a multiple logistic regression to model the role of environmental variables (vegetation type, soil type, altitude, slope, rainfall) on the Southern Amazonian cropland dynamics previously assessed using remote sensing data. More recently, Arvor et al. (2014) showed that the adoption of intensive double-cropping practices was related to the spatial variability of rainfall regimes and favored by a high annual rainfall, a long rainy season and a low variability of the onset date.

However, a major drawback of the spatial allocation models approach is that it is not always possible to obtain deterministic relations between easily accessible factors (climate, soil, etc.) and cropping system elements, especially in "intensive systems" compared to "traditional systems", which are more dependent on environmental factors (Figure 4). According to Jouve (2006), in southern countries where traditional systems are important and make little use of modern means of production (mechanization, fertilization), the farmers capacity to artificialize their environment and get rid of the environmental constraints is limited. In those cases, the relationship between the cropping systems and environmental conditions is strong, and the spatial distribution of the cropping systems reflects more the environmental differences than the farming differences. Additionally, the relationship can be identified at the rural community scale. Inversely, in intensive systems, the determining factors approach is more difficult to set up and the spatial allocation models can be more difficult to implement.

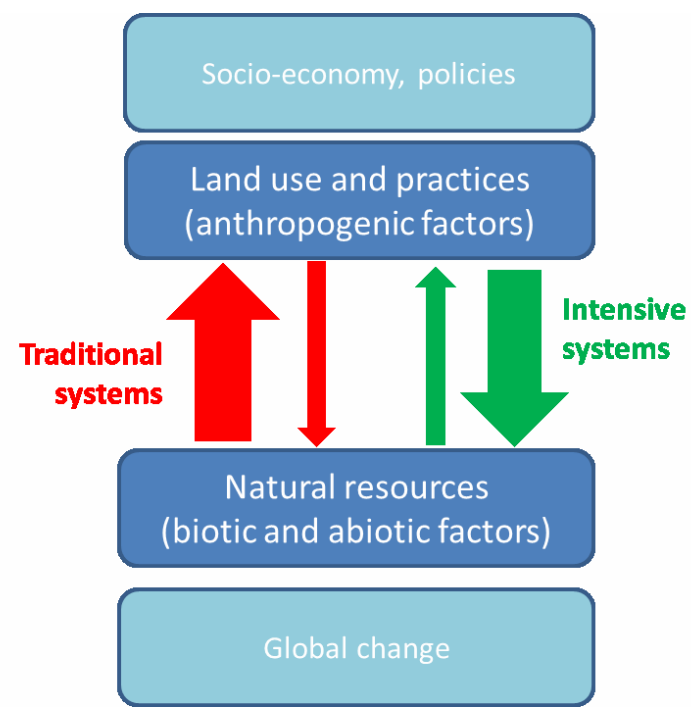

Figure 4. Relative weights of the determining factors in the traditional and intensive agricultural systems. 


\section{Examples of Agricultural Systems Studies using Remote Sensing}

Three case studies - agroforestry in Bali (Indonesia), double cropping in Southern Amazon (Brazil), and traditional rainfed agriculture in Mali - were selected to illustrate the use of remote sensing for mapping agricultural systems. Two of them, Bali and Mali, are characterized by smallholder agriculture, while the Brazilian case is characterized by commercial agriculture (Figure 1b). These case studies are far from representing all of the possible uses of remote sensing, but they illustrate a diversity of technical and scientific approaches, while addressing some worldwide agricultural issues (geographic certification, agricultural system sustainability, food security, etc.).

\subsection{Presentation of the case studies}

\section{Agro-forestry in Bali}

In tropical regions, small stakeholders' agroforestry is the most common traditional cropping system. It associates different crops inside a single plot, with multifunctional trees to produce fruits, cash-crops, wood, medicines, shading, or to conserve biodiversity in various proportions and organizations. This system allows a relative sustainability in food diversification, but not in incomes, which depends on the trading market fluctuations. Agroforestry is promoted by agronomists for environmental and livelihood quality, and is questioned by socio-economists because of the cash-crop vulnerability. This emphasizes the need for evaluating the actual environmental, social and economic benefits of such cropping system. Remote sensing studies now propose new tools to objectively characterize the agroforestry systems at the intra-plot scale (Coltri et al., 2013; Guillen-Climent et al., 2014; Peña-Barragán et al., 2004; Aksoy et al., 2012; Ursani et al., 2012; Mougel and Lelong, 2008), at the farm level (distribution among neighbors), and to replace it in the landscape matrix (Wästfelt et al., 2012; Lei et al., 2012). This allows associating different environmental, agricultural, and socioeconomic conditions in integrated analyses to understand the drivers of agricultural choices and resilience (Fox et al., 1994; Gobin et al., 2001; Kunwar, 2010), and the level of productivity and quality of the production.

The case study presented in this chapter is situated in Bali, an active volcanic island of Indonesia. Coffee is cropped almost everywhere in the central highlands. The study focused on a $220 \mathrm{~km}^{2}$ area located in Kintamani county which is famous for its coffee crops. The landscape is shaped by the local topography, which ranges from $300 \mathrm{~m}$ to $1800 \mathrm{~m}$ (Figure 5). This work aims at producing a cropping system map in order to understand coffee quality drivers, and helps delimitating an area labeled by the distinction of the Protected Geographical Indication on Arabica coffee.

\section{Double cropping in Southern Amazon}

For nearly forty years, the Southeastern Amazon in Brazil experiences severe agricultural dynamics. Cropland expanded dramatically to support commercial cultivation of important 11 
commodities such as soybean, maize, and cotton. The severity of the agricultural dynamics explains the abundance of large-scale monitoring studies using remote sensing. To date, most remote sensing based studies were carried out with MODIS data for three reasons: (i) monitoring such a large area requires a huge number of high remote sensing data to be processed, (ii) high cloud cover rates during the rainy season prevents the acquisition of good quality high resolution images during the cropping period, and (iii) the mean field area is about 180 ha so that even $250 \mathrm{~m}$ medium resolution images are valid for crop type mapping. Consequently, most MODIS-based approaches to date were based on the interpretation of vegetation index (NDVI or EVI) time series. Such time series have long been successfully used to estimate cropland areas thus evidencing the rapid agricultural expansion during the $2000 \mathrm{~s}$ (Anderson et al., 2003; Morton et al., 2006).

In Mato Grosso state, Arvor et al. (2012) estimated that net cropped areas increased by $43 \%$ between 2000 and 2007, reaching an area of $55988 \mathrm{~km}^{2}$. In the same time, farmers adopted new agricultural management practices to intensify the production process. The cultivation of two successive crops, as soybean and cotton, benefits from a long rainy season (Arvor et al., 2014) and regular rainfall from mid-September to late May. In this context, the Mato Grosso case study aims at producing a cropping system map showing the main crop type and the intensification practices in relation to the rainfall, and a land use system map to analyze the agricultural transition in Mato Grosso.

\section{Rainfed agriculture in Mali}

In the Sudano-Sahelian region, farming is the main source of income for many people, where millet and sorghum are the main food crops. The vast majority of the population (80\%) consists of subsistence farmers. A few larger farms produce crops for sale (cash crops), mainly cotton and peanuts. In the Sudano-Sahelian zone, the strong dependence on rainfed agriculture implies exposure to climate variability in addition to the impacts population growth have on food security. Key deliverables of food security systems for crop monitoring consist of early estimates of cultivated area and crop-type distribution, cropping practices, detection of growth anomalies, and crop yield estimates. Unfortunately, the national statistics can be deficient in insecure countries, and remote sensing has an important role to play in delivering information for crop monitoring (e.g., Hutchinson, 1991; Thenkabail et al., 2009). Remote sensing techniques face numerous challenges for crop mapping in regions where the cropland is fragmented, made of small, highly heterogeneous fields covered with many trees. In Mali, Vintrou et al. (2011) showed that $20 \%$ to $40 \%$ of cropland classification errors using MODIS is inherent to the structure of the landscape.

Southern Mali case study aims at producing farming system map (food-producing, intensive, and mixed agricultures) in support to food security analyses (USAID, 2009). Because local factors, such as climate, soil, water availability, access to markets, and fertilizers influence the agricultural systems, mapping these systems can help determine which region and which population may be vulnerable to different hazards. Additionally, the cropping system map can 
be used for spatialized agro-meteorological modeling and forecasting at regional scales (see example in Vintrou et al. (2014).

\subsection{Remote Sensing data and methods}

The data (remote sensing images, ancillary data) and methods used to produce agricultural maps are presented in Erreur ! Source du renvoi introuvable. for the three case studies.

Table 3. Typology, data and methods used to produce agricultural system maps for the three case studies.

\begin{tabular}{|c|c|c|c|c|c|}
\hline $\begin{array}{l}\text { Case study } \\
\text { (area) }\end{array}$ & $\begin{array}{l}\text { Agriculture } \\
\text { type }\end{array}$ & $\begin{array}{l}\text { Satellite data } \\
\text { (acquisition } \\
\text { year) }\end{array}$ & Other data & Method & Map products \\
\hline $\begin{array}{l}\text { Bali island } \\
\left(224 \mathrm{~km}^{2}\right)\end{array}$ & $\begin{array}{l}\text { Smallhoder } \\
\text { agriculture }\end{array}$ & $\begin{array}{l}\text { QuickBird } \\
\text { bundle - } \\
\text { (2003) }\end{array}$ & $\begin{array}{l}\text { DEM } \\
760 \text { ground } \\
\text { survey } \\
\text { points }\end{array}$ & $\begin{array}{l}\text { Spatial analysis } \\
\text { (majority filter; } \\
1 \text { ha window) }\end{array}$ & $\begin{array}{l}\text { Farming } \\
\text { system } \\
\text { (agrosystem) }\end{array}$ \\
\hline $\begin{array}{l}\text { Mato Grosso } \\
\left(906000 \mathrm{~km}^{2}\right)\end{array}$ & $\begin{array}{l}\text { Commercial } \\
\text { agriculture }\end{array}$ & $\begin{array}{l}\text { MOD13Q1 } \\
\text { EVI product - } \\
(2005-2008)\end{array}$ & & $\begin{array}{l}\text { Landscape } \\
\text { analysis (land } \\
\text { cover and land } \\
\text { use classes } \\
\text { metrics; } 770 \mathrm{~km}^{2} \\
\text { window) }\end{array}$ & $\begin{array}{l}\text { Crop type } \\
\text { Cropping } \\
\text { system } \\
\text { Farming } \\
\text { system }\end{array}$ \\
\hline $\begin{array}{l}\text { Southern Mali } \\
\left(165790 \mathrm{~km}^{2}\right)\end{array}$ & $\begin{array}{l}\text { Smallhoder } \\
\text { agriculture }\end{array}$ & $\begin{array}{l}\text { MCD12Q2 } \\
\text { phenology } \\
\text { product - } \\
(2007)\end{array}$ & $\begin{array}{l}\text { Cropland } \\
\text { map at } \\
250 \mathrm{~m} \\
\text { resolution. } \\
\text { Climate } \\
\text { type, DEM } \\
\text { and } \\
\text { population }\end{array}$ & $\begin{array}{l}\text { Landscape } \\
\text { analysis (land } \\
\text { cover classes } \\
\text { metrics; } 100 \mathrm{~km}^{2} \\
\text { window) }\end{array}$ & $\begin{array}{l}\text { Farming } \\
\text { system }\end{array}$ \\
\hline
\end{tabular}


In Bali, a multispectral QuickBird image at $0.6 \mathrm{~m}$ resolution was photo-interpreted to delineate the field limits and identify six cropping systems based on the field survey: citrus monocrop, coffee monocrop without shade, coffee associated with light shadow (citrus), coffee under dense shadow (erythrina, albizias, leucaenas, etc.), clove crops associated or not with coffee, and food-crops. An agrosystem map was then obtained by applying a majority filter (1 ha square corresponding to a dozen of crop plots) on the cropping system map, and was defined by its upper vegetation layer in four classes: citrus, clove, dense shading trees, and food crops. The term agrosystem is preferred here to the term farming system whose definition goes beyond what is studied in this case.

In Mato Grosso, MOD13Q1 EVI products acquired from 2005 to 2008 period, were used to produce a cropping system map showing the main crop types (soybean, corn and cotton), and their intensification practices (mono and double-cropping). Arvor et al. (2013a) used a landscape approach to better characterize the land use system across the state. The strategy consisted of applying a regular grid where each cell represented an approximation of a district territory (a district was considered as an administrative sub-level, below the municipality level). There were 1175 districts in Mato Grosso, a total of $906000 \mathrm{~km}^{2}$, and the grid cell was fixed at $25.75 \times 27.75 \mathrm{~km}^{2}$, approximating an area of $770 \mathrm{~km}^{2}$. A set of landscape indices was then computed for each cell based on MODIS-based land use classifications and deforestation maps. Those indices referred to the proportion of wilderness areas, the proportion of cropped areas in deforested areas, and the proportion of intensive practices observed in cropped areas. Some thresholds were applied to identify different land use systems, such as pre-settlement area, noncropland occupation, cropland occupation, non-cropland consolidation, cropland consolidation, non-cropland intensifying, cropland intensifying and intensive cropland.

In Mali, the field size and MODIS spatial resolution prevent from producing a crop type map. We then mapped directly the farming system map using a 3-class typology. This typology was defined at the village scale, and based on a field survey carried out in 100 villages in Southern Mali (Soumare, 2008). The typology was created using expert knowledge, and considering the main crop types cultivated in the village and the intensification of production (use of fertilizers, equipment, livestock, etc.): the "food-producing agriculture" class groups the millet and sorghum-based agricultural systems, the "intensive agriculture" class includes farms with maize and cotton, and the "mixed agriculture" class encompasses farms where both coarse grain (sorghum) and a cash crop (cotton) are found (Vintrou et al., 2012). A random forest algorithm (Breiman, 2001) was trained on the 100-village data set, and on a set of 30 variables composed of 4 spectral metrics (annual maximum, annual mean, annual amplitude, and seasonal mean from May through November; MOD13Q1 product), 12 texture indices (maximum and mean of the variance and skewness indices, calculated with a pattern size of seven MODIS pixels for March, June, and September; MOD13Q1 product), 7 phenology metrics (MCD12Q2 product), 3 spatial metrics (the fraction of cropped area, number of cultivated patches, and the mean cultivated patch size inside a $10 \times 10 \mathrm{~km}^{2}$ area centered on the village; MCD12Q1 product), 3 
environmental indices (climate type, maximum and mean of elevation), and 1 population indice. All of the indices were extracted for cropland only. The random forest model trained on the 100 -village ground survey, was applied to the 4000 villages in South Mali.

\subsection{Results}

\section{Agroforestry in Bali}

In Bali, the cropping system map is presented in Figure 5a. Photointerpretation performed on the ground-truth plots showed that confusion between citrus and coffee under citrus is less than $10 \%$, whereas other class errors lie below $2 \%$. The analysis of the distribution of each cropping system showed that the most frequent are the citrus-based crops (18\%) and those shaded by large trees (15\%), followed by the food-crops (12\%), and the associated coffee and citrus crops $(10 \%)$. The mean size of a plot is approximately 0.7 ha, but the clove plots are generally bigger (1.2 ha) and the food-crops are smaller (0.3 ha).

The agrosystem map is presented in Figure 5b. The citrus-based agrosystem is largely dominant. Coffee, as being cropped below the dominant trees, does not appear in the map legend. 


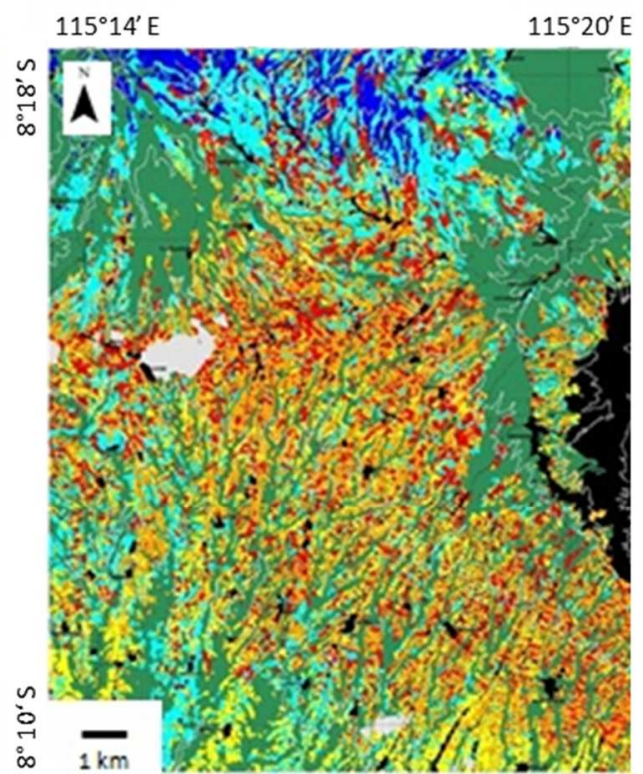

a) Cropping system based on:

Settlement/uncropped area
Forest
Dense shading trees
Clove
Coffee under citrus
Coffee without shade
Citrus
Food-Crop

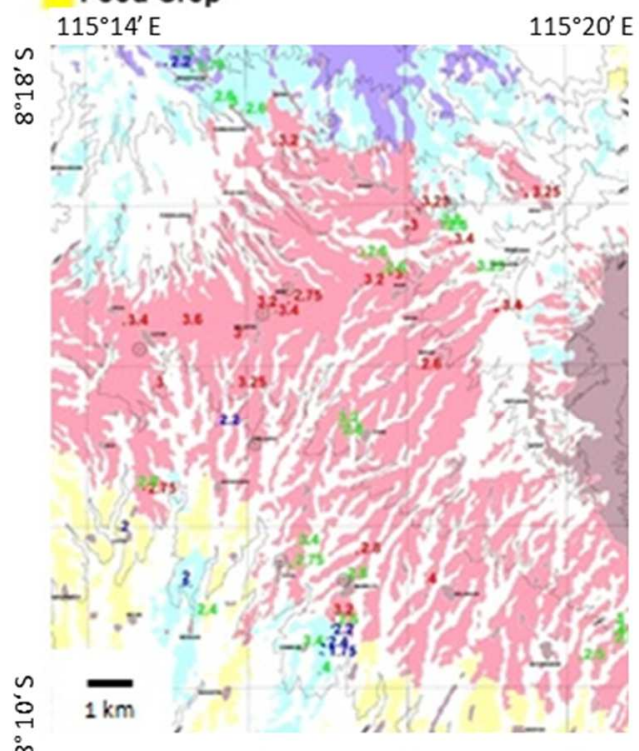

c) Overall quality notation for:

Good coffee

Standard coffee

Bad coffee

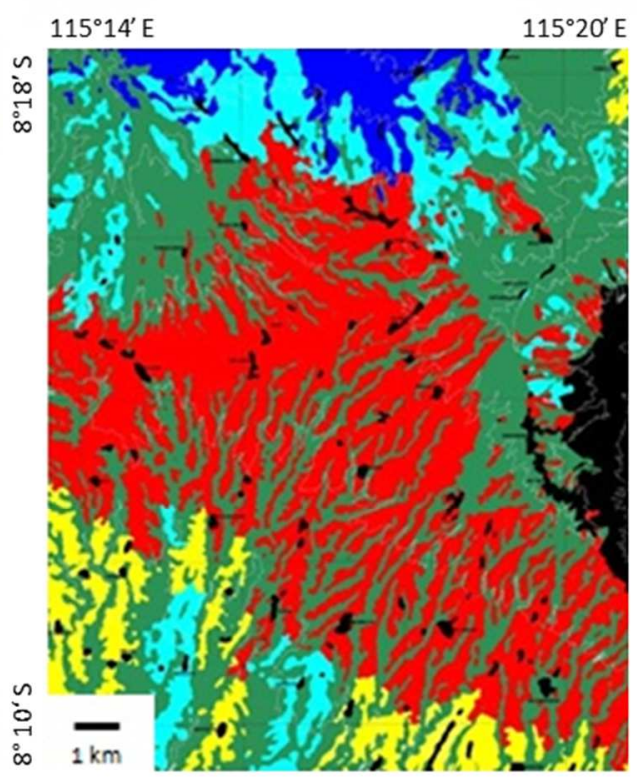

b) Agrosystem based on:

Settlement/uncropped area
Forest
Dense shading trees
Clove
Citrus
Food-Crop

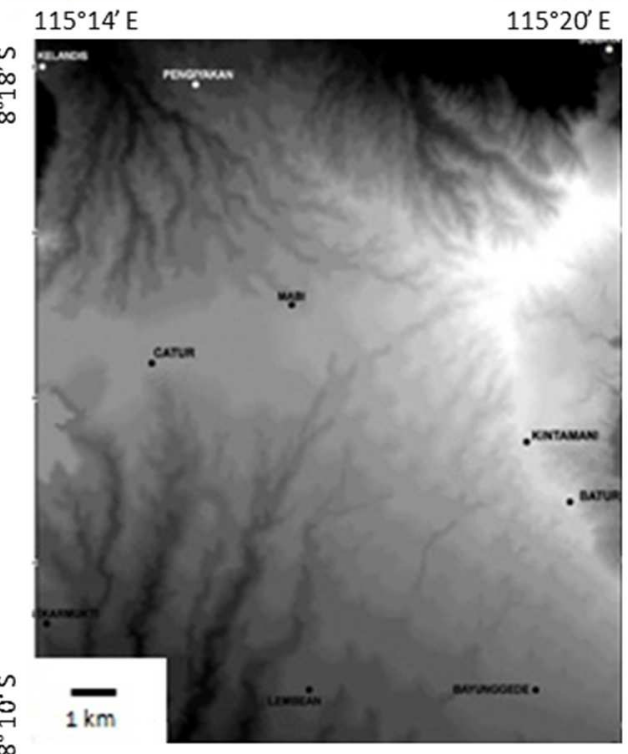

d) Altitude

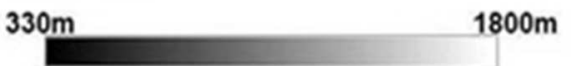

Figure 5. Map products in Central Bali: a) main cropping systems map derived from QuickBird image visual interpretation, b) agrosystems map derived from spatial analysis of the cropping system map, c) location map of 40 sampled coffees and quality notation rate for each type of aromatic value, and d) Digital Terrain Model derived from topographic maps. 
At first glance, the cropping system and agrosystem spatial distribution looks complex because of a number of factors, such as a North/South contrast, altitude, and local geographic characteristics, such as river network density, slope, exposition to wind, and the presence of lava-flows and forests. The cropping and agrosystem maps were then used to analyze the distribution of each agricultural system, in relation to altimetry because of the strong relationship between coffee quality and altitude (Florinsky, 1998; Wintgens, 2004; Montagnon, 2006). The area covered by all of the different cropping systems is plotted for each $100 \mathrm{~m}$ altitude bin, between $1000 \mathrm{~m}$ and $1800 \mathrm{~m}$ in Figure 6a, while Figure 6b represents the altitude distribution for the area covered by the coffee-based cropping systems alone. The two principal coffee-based cropping systems were found to be those dominated by citrus or dense shading trees. The former is most common at high altitudes (64\% from $1200 \mathrm{~m}$ to $1400 \mathrm{~m}$ ), while the latter dominates coffee crops at lower altitudes $(68 \%$ below $1100 \mathrm{~m})$. The third coffee-based cropping system, dominated by clove shading, covers a small acreage and is spatially restricted. It is present at the lowest altitudes, mainly below $1100 \mathrm{~m}(68 \%)$ and $1200 \mathrm{~m} \mathrm{(28 \% ).} \mathrm{The}$ unshaded coffee monoculture is not typical in this territory.

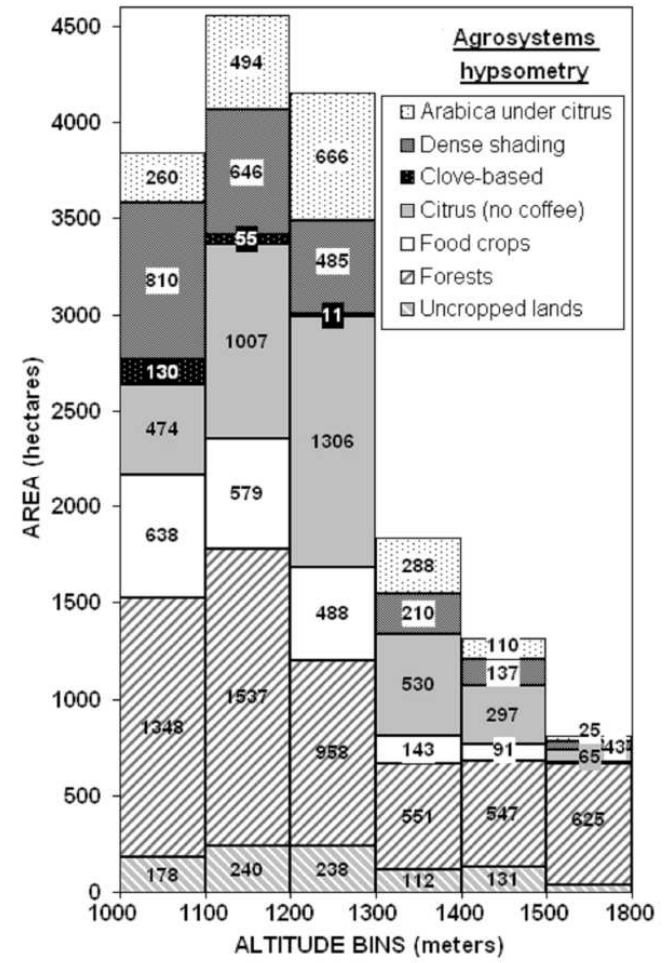

a)

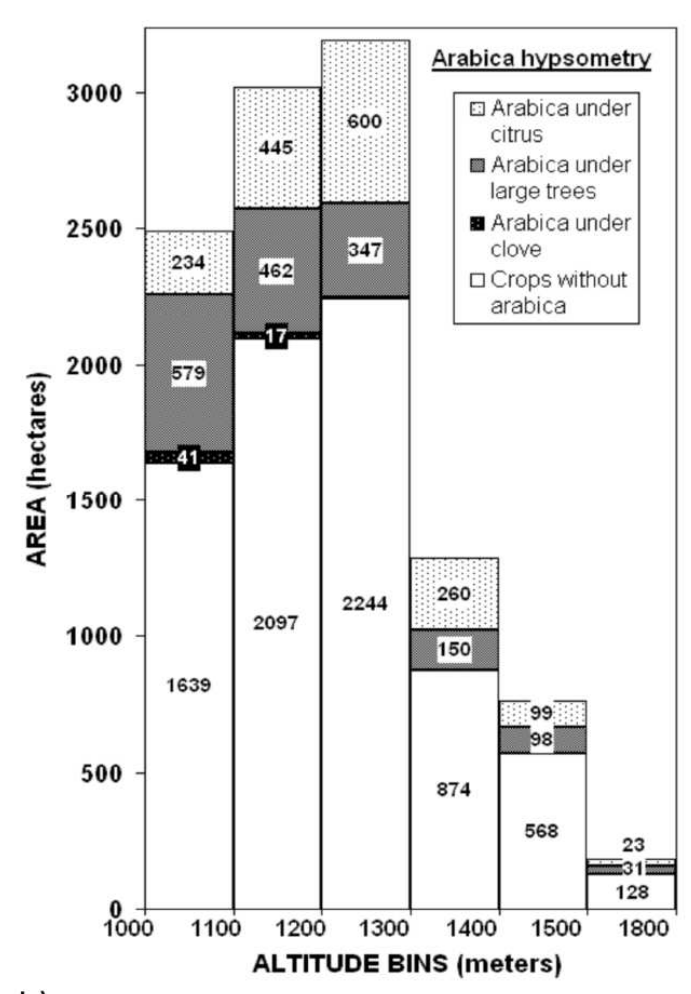

b)

Figure 6. Areal altimetry distribution per bin of $100 \mathrm{~m}$ between $1000 \mathrm{~m}$ and $1800 \mathrm{~m}$ in Kintamani territory in Bali: a) per cropping system class, and b) per coffee-based cropping system class (Arabica monocrop is not displayed because it covers less than 2 ha).

The coffee samples location and sensorial quality rates were plotted in both the cropping and agrosystem maps to understand the spatial distribution of the coffee characteristics at the two scales (Figure 5c). A landscape analysis provided spatial and topographic distribution information about the three coffee quality classes, and helped to identify the relationships 17 
between quality of coffee beans and the local and regional environment. This integrated analysis suggests that good coffee is only found in the citrus-dominated agrosystem, even if it is not cultivated in association with citrus at the plot level, and cropped above $1200 \mathrm{~m}$. This area was validated by both the coffee farmers and the traders, and accepted by the Indonesian Government as the official limits of the labeled territory.

\section{Double cropping in Southern Amazon}

Time series of vegetation indices were used to detect crop types and cropping practices using an analysis of agricultural calendars. The producers undertake two successive harvests per rainy season: they cultivate soybean from late September to early February, and then cultivate maize or cotton until June or July. The double cropping systems show very different patterns in their vegetation index time series and can be easily discriminated (Arvor et al., 2011). The user's and producer's accuracies of the cropland were higher than 95\%. Main crop types were also correctly detected
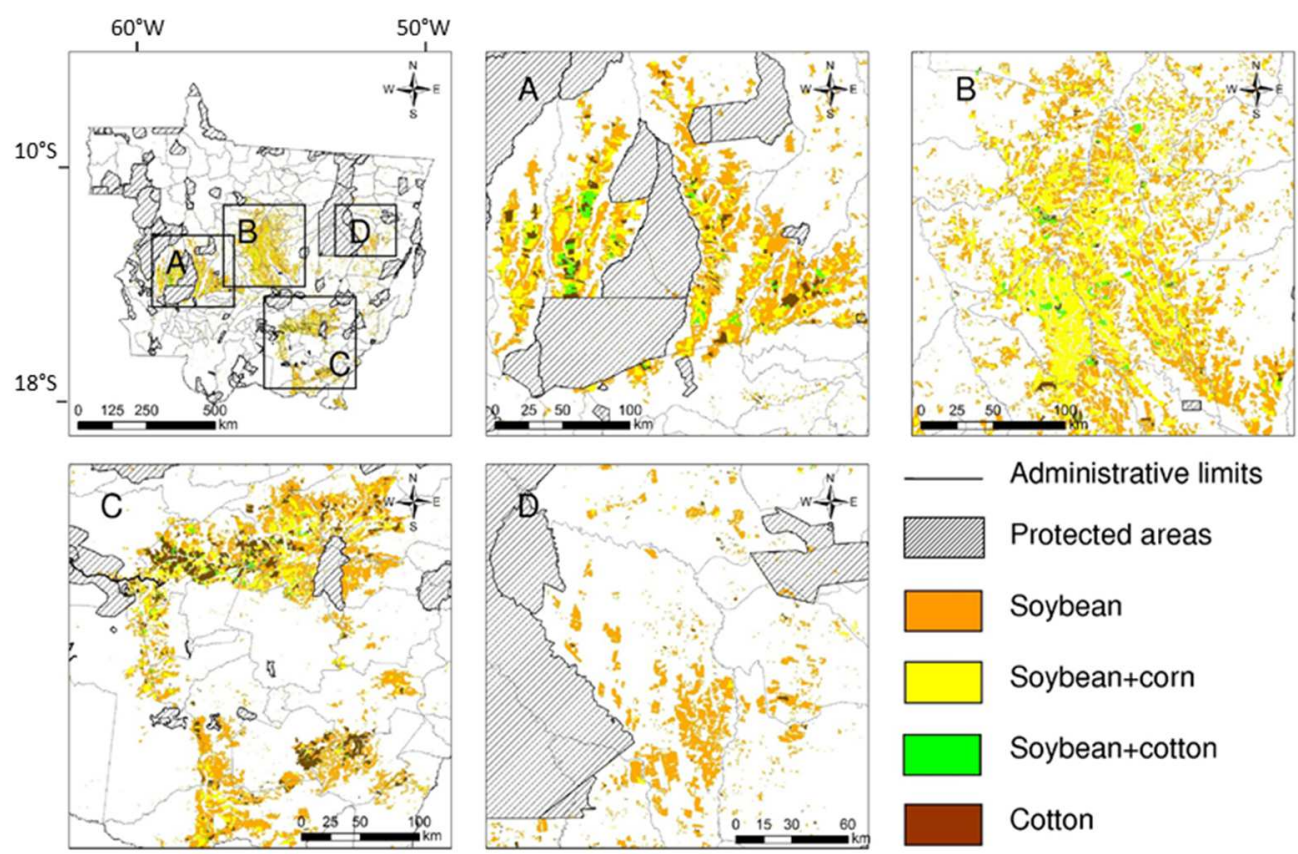

Figure 7) with good Kappa index (0.68) and overall accuracy (74\%). Once the double cropping classes are grouped (i.e., the "soybean + corn" and "soybean + cotton" classes; Figure 8a), the user's and producer's accuracies increased up to of $95 \%$ and $86 \%$, respectively. The main uncertainties to be considered in these maps refer to sorghum or millet that is sometimes sown after the soybean harvest (to prevent soil erosion from intense rainfall) and can thus be confused with maize. Such issue highlights a main limitation of EVI time series-based classification (different crops with similar agricultural calendars may be confused) that could be overcome with a better spatial and radiometric resolution (since only Blue, Red and NIR bands are used to compute the Enhanced Vegetation Index used in that work). 

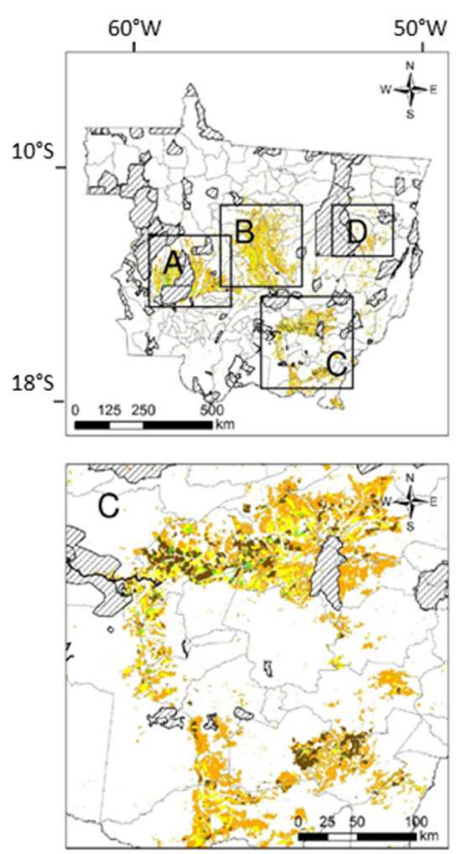
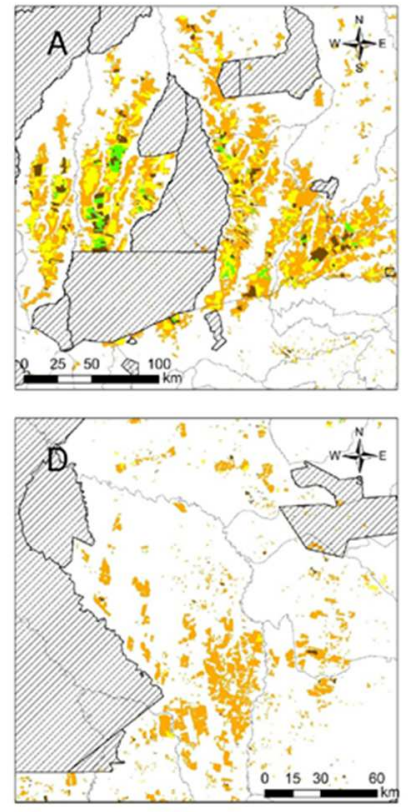

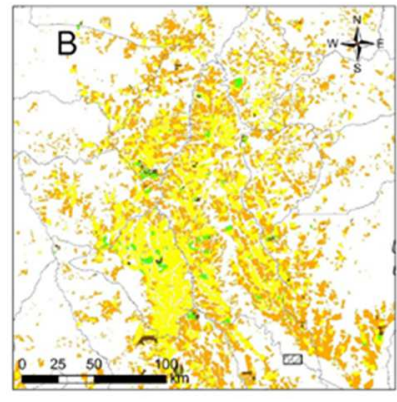

Administrative limits

Protected areas

Soybean

Soybean+corn

Soybean+cotton

Cotton

Figure 7. Maps of the three main crop types (soybean, corn and cotton) for the 2006-2007 harvest for the four main agricultural regions in Mato Grosso: (A) Parecis plateau, (B) along the BR163 highway, $(C)$ southeastern region (D) eastern region (Arvor et al., 2011). Maps were obtained through supervised classification of MODIS vegetation index (EVI) time series.

Beyond such limitations, those results are in agreement with results obtained by different authors (Galford et al., 2008; Arvor et al., 2011; Brown et al., 2013) who successfully mapped double cropping systems in Mato Grosso and confirmed the generalization of such intensive practices. Arvor et al. (2012) estimated that the proportion of croplands permanently covered by double-cropping vegetation during the rainy season increased from $35 \%$ to $62 \%$ between 2000 and 2007. This trend raises a major issue regarding the sustainability of cropland systems in Mato Grosso. Fu et al. (2013) proved that the length of the rainy season is decreasing in the southern Amazon, which leads to the question of whether the adoption of double cropping practices would still be viable in the changing climate. Even if intensive practices are a relevant strategy to contain deforestation, it raises new issues regarding agricultural sustainability in that region.

The land use system map shows a good overview of the soybean agricultural frontier in the southeastern Amazon (Figure 8b). It demonstrates the efficiency of public policies to simultaneously contend deforestation (through the creation of protected areas) and encourage crop expansion (through the construction of important infrastructures, such as the Transamazonian roads). 


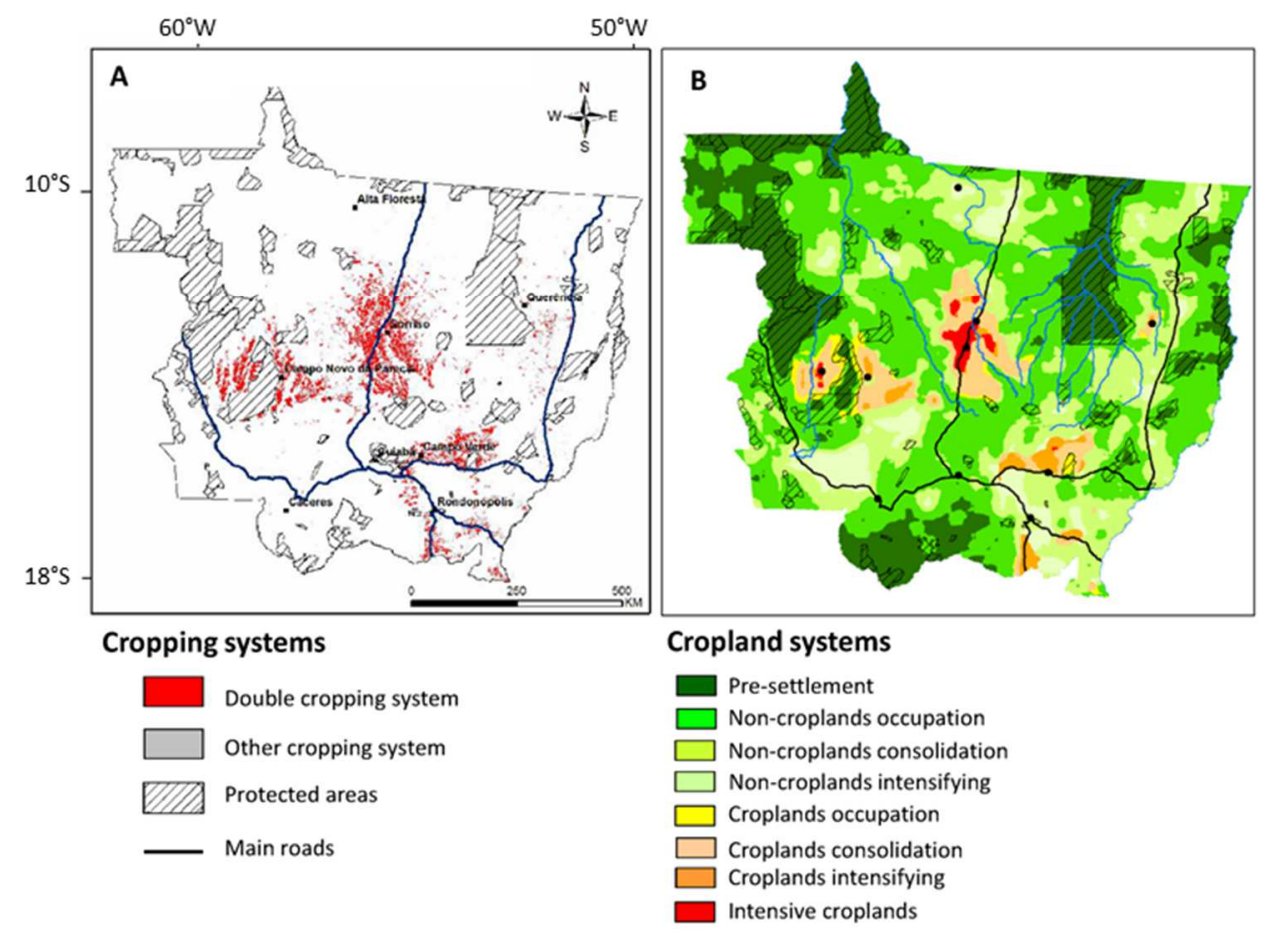

Figure 8. Maps of (A) cropping systems and (B) land use systems obtained from MODIS vegetation index time series and landscape analysis for the 2006-2007 harvest (from Arvor et al., 2012; Arvor et al., 2013a). 


\section{Rainfed agriculture in Mali}

The Random Forest model classified the agricultural systems with an estimated overall accuracy of $60 \%$ calculated from Out-Of-Bag observations (

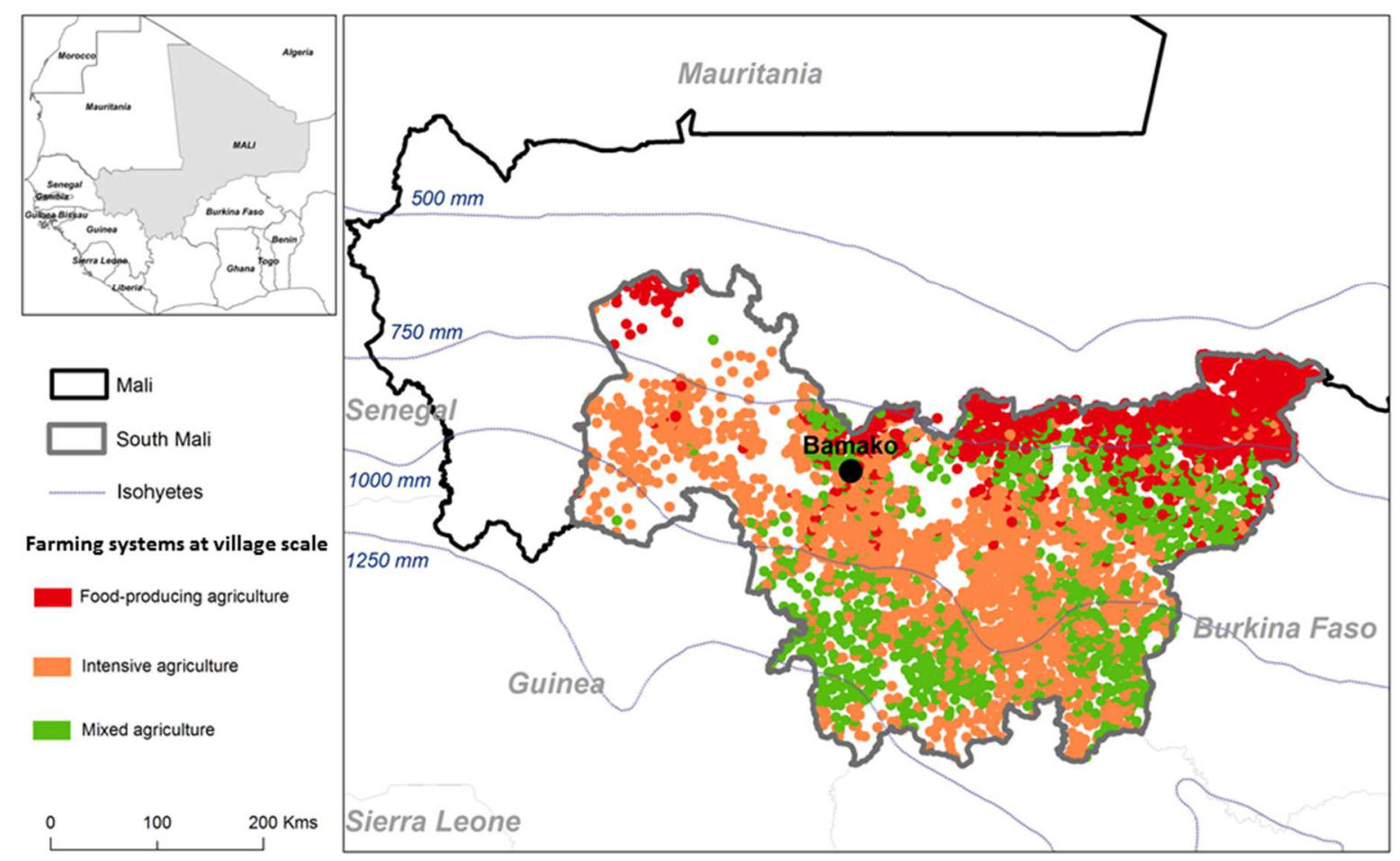

Figure 9). The "food-producing agriculture" class was dominant in the Sudano-Sahelian part of the area. Sorghum and millet are well adapted to this zone because they are resistant, and have a short growth cycle of about 90 days. In the traditional cotton basin, the dominant system is agro-forestry/pastoral agriculture mainly with rainfed crops. Agriculture is focused on cotton, the main cash crop, and corresponds to the class "intensive agriculture". The Sudanian zone part of the area is also a cotton-based system zone, but is more diversified, with the simultaneous presence of "intensive agriculture" and "mixed agriculture" systems. The length of the rainy season in this region makes it possible to grow a wide range of species. Farmers usually cultivate different species and varieties to ensure a certain degree of production stability.

Class errors ranged from $30 \%$ to $50 \%$. Globally, producer's and user's accuracies were reasonably balanced for each class (less than 10 percent difference), meaning that the village agricultural systems were estimated correctly. Misclassifications can be explained by three main factors: (i) the small size of the crop patches compared to the $250 \mathrm{~m}$ spatial resolution of MODIS sensor, and the natural and crop vegetation seasonal synchronization due to a short rainy season, (ii) the size of the training data set (100 villages), and (iii) the definition of the classes (a rough proportion of different crop types, and crop intensification variables) that is expert dependent and includes variables that cannot be directly related to landscape features. 


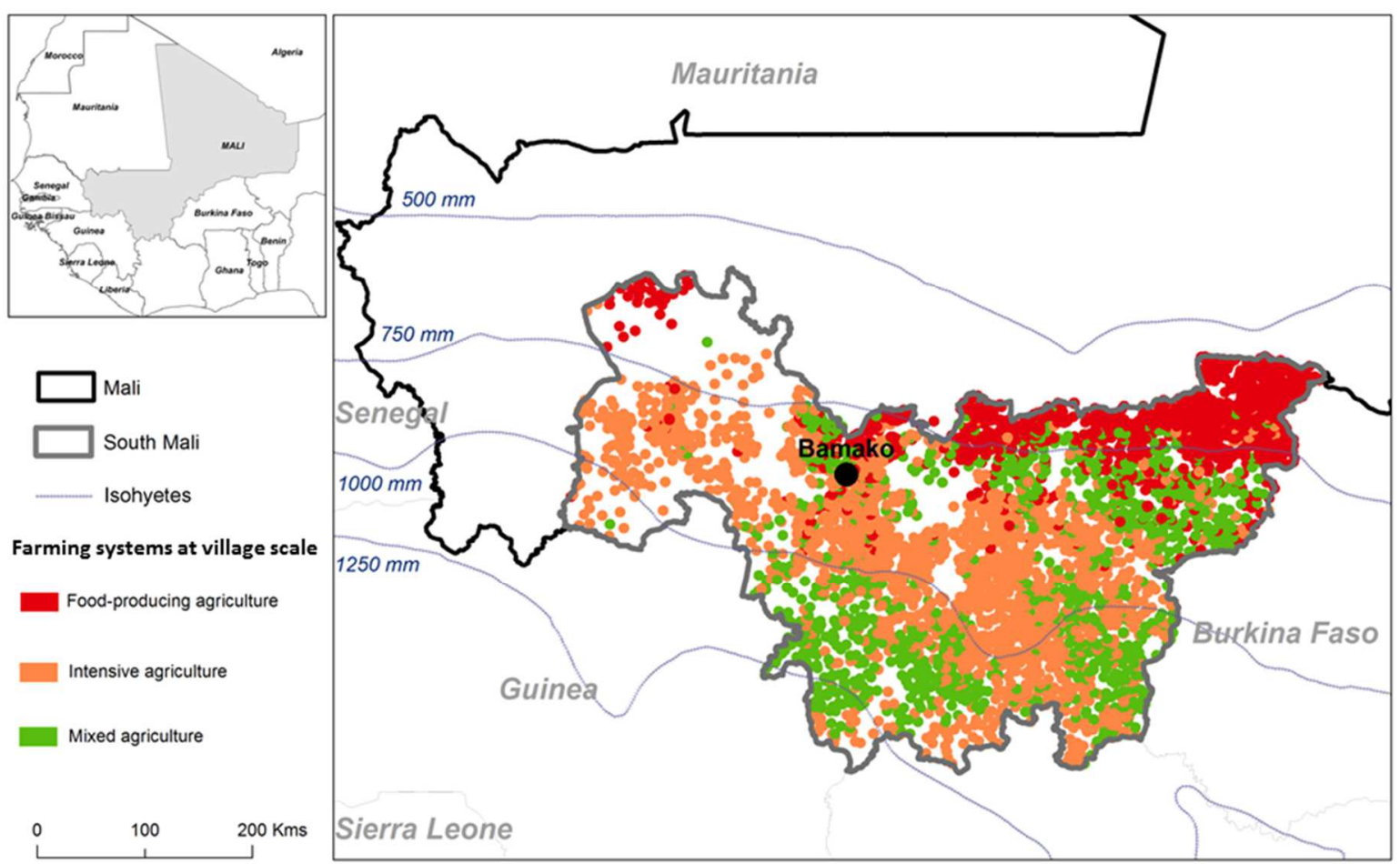

Figure 9. Village-based farming systems in South Mali predicted by the Random Forest model (Vintrou et al., 2012). The model was based on 100 village samples, and 30 MODIS-derived and socio-environmental metrics calculated on agricultural areas.

The analysis of the contribution of the different metrics (Figure 10) shows the role of the texture of the MODIS images in the classification of the cropland, even if the fields are not visible at the MODIS resolution. The field crop information is hidden in these broad images, but can be identified with landscape metrics, such as image texture indices. This indirect analysis was confirmed by Bisquert et al. (2014) who showed that the texture of broad-scale images is an important variable for land stratification in relation to land cover, even if the land cover units are not detectable.

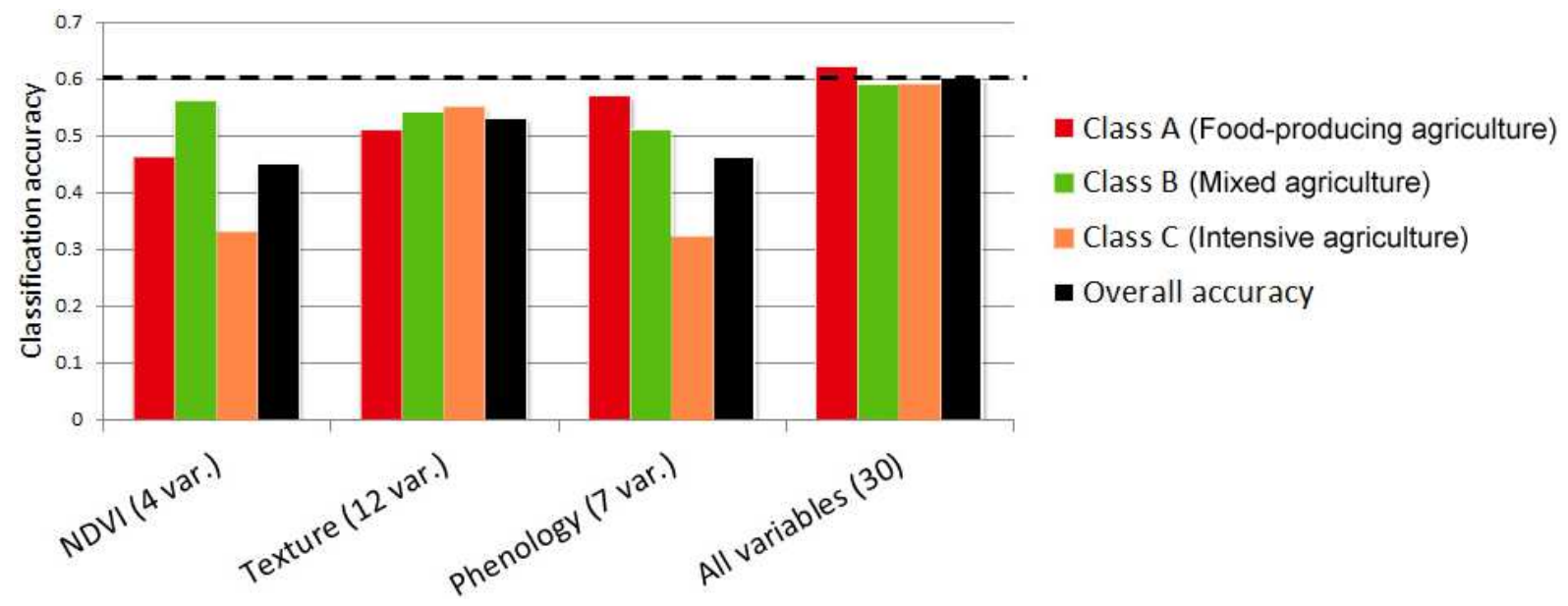

Figure 10. Accuracy of class and overall classification of Random Forest run with different 


\section{Discussion}

While remote sensing approaches have proven to be efficient for cropland (land cover) mapping, they still remain ill-suited for cropping system (land use) monitoring at the regional and global scales because of their inability to distinguish crop types and the associated practices (Monfreda et al., 2008). In this section, we consider the main present limitations of remote sensing studies for regional mapping of cropping systems, and introduce some emerging research areas to overcome such limitations. We then discuss the opportunity to work on an extended landscape agronomy approach.

\subsection{Difficulties of mapping the cropping systems at regional scales}

Remote sensing-based land use maps suffer from uncertainties related to the spatial and temporal resolutions of the observing system, and to the landscape structure.

The spatial resolution issue is particularly true for smallholders agriculture (Figure 1b), for which remote sensing data are unable to resolve individual fields (Ozdogan, 2010). Rather than a sensor resolution issue, it should actually be considered as a scale issue to be addressed through the concept of H-resolution and L-resolution (Strahler et al., 1986; Blaschke et al., 2014). H- and L-resolution terms are different from high and low spatial resolution images as generally mentioned in remote sensing studies. In the latter, the resolution refers to the sensor spatial resolution independently of the geographic objects concerned. H-resolution model is valid when scene objects are much larger than the image spatial resolution, thus several pixels may represent a single object (a field, a tree ...). Meanwhile, L-resolution model is when objects are much smaller than the image spatial resolution. An image may contain both $\mathrm{H}-$ and Lresolution information (Hay et al., 2001). Marceau et al. (1994) place the limit between $\mathrm{H}$ - and L- when the dimension of the resolution cells is $1 / 2$ to $3 / 4$ the size of the objects of interest in the scene. This threshold should be a guide for assessing whether the analysis should be performed at $\mathrm{H}$ - or L-resolution.

- For an H-resolution situation - agricultural fields in Mato Grosso using MODIS sensor - a cropping system can be assessed directly by characterizing crop types and their associated cropping practices using inner field information (derived from relatively pure pixels).

- For an L-resolution situation - cropped trees in Bali using QuickBird sensor or cropped fields in Mali using MODIS sensor - pixels correspond to a mixture of different crop (or trees) types and other landscape elements (natural vegetation, water bodies, buildings, roads, etc.).

The temporal resolution issue in crop mapping is highly dependent on the environmental and agronomic conditions. For example, in tropical dry areas where rainfall is the main driver of vegetation growth (e.g., the Sahelian part of Mali), natural and cultivated vegetation are difficult to separate using phenology. In equatorial areas (e.g., Bali) characterized by a low seasonality, it is difficult to discriminate crops due to fluctuating crop calendars. However, even in regions with contrasted seasons (e.g., Mato-Grosso), different cropping systems with similar agricultural calendars cannot be separated using MODIS EVI time series. A better temporal 
resolution (less than 16 days) would surely improve crop discrimination in most of the agricultural systems.

The quality of the land maps produced by image pixel-based classification, is usually evaluated using a set of indices (producer's accuracy, user's accuracy, overall accuracy and Kappa index) which are commonly calculated from an error matrix (or confusion matrix; see Congalton and Green, 1999). While such accuracy metrics have been widely accepted by the scientific community for a long time, they have also been regularly criticized (Pontius and Millones, 2011). These metrics tell nothing about the source of error that can be linked to the performance of the classification algorithm, or to the resolution of the remotely sensed data (Boschetti et al., 2004). For instance, Vintrou et al. (2011) using the Pareto boundary method showed that in Mali, $20 \%$ to $40 \%$ of cropland classification errors using MODIS data is inherent to the landscape structure. In this context, new processing and evaluation approaches are required to better consider landscape properties in order to overcome these limitations and allow an efficient monitoring of farming systems at regional scale.

\subsection{Emerging remote sensing research}

There was a challenge in land cover mapping in the 2000's, and today, there is a challenge in land use system mapping. It is an emerging area for the remote sensing community that needs to focus on land use and land function (Verburg et al., 2009). It requires developing new data, methods, and a further integration of the disciplines involved in land science research. These developments are presented hereafter according to the resolution situation (the direct and direct cases).

When the landscape elements are larger than the pixel size (H-resolution situation), many examples in the literature showed that cropping practices can be directly assessed (Erreur ! Source du renvoi introuvable.). Except for rare examples of mapping crop type and cropping intensity in regions where the size of the plots is compatible with broad scale sensors (Mato Grosso case study), the research was mainly developed at local scale, and for one practice at a time. To further characterize regional scale cropping practices, research needs to focus on developing automatic or semi-automatic crop type classification procedures, and on the combination of different sensors to catch different practices in the same area. Another way to work at broader scales is to properly translate local findings to larger regions by using case study results from specific land functions (Verburg et al., 2009). This approach needs to define the spatial extent and function for the local studies representative of a region. Land stratification into homogeneous landscape units could be a way to reach this objective. Bisquert et al. (2014) showed that processing broad-scale remote sensing data with spectral and textural segmentation techniques permit to delineate radiometrically homogeneous landscape that were consistent in terms of land cover.

When the landscape elements are smaller than the pixel size (L-resolution situation), research needs to focus on the role of landscape as a mean to characterize the cropping systems. Research on landscape metrics for agricultural systems characterization must be pursued and enhanced. 
Furthermore, given the multidimensional nature of agricultural systems, focusing on multiple metrics within a systems perspective is needed (Kuemmerle et al., 2013). As the current approaches based on the remote sensing data are not sufficient to develop a comprehensive understanding of situational changes for multiple land functions, remote sensing-based metrics should be completed by other types of metrics, such as socio-economic descriptors (demography, ethnic spatialized data, etc.). To merge heterogeneous information, new data processing tools, such as fuzzy logic and data mining tools (Vintrou et al., 2013; Korting et al., 2013), must be tested to characterize and map agricultural systems and processes.

To implement both approaches (direct and indirect), the scientific community should benefit from recent promising advances in remote sensing such as GEographic Object-Based Image Analysis (GEOBIA) and ontologies. GEOBIA is based on the hypothesis that partitioning an image into objects is related to the way humans conceptually organize the landscape to comprehend it (Hay and Castilla, 2008). It is actually based on two main components. First, a segmentation delineates regions (objects) of the image that have common attributes. Second, the approach incorporates the user (expert) knowledge in the image processing operation to produce reliable maps. However, to date, GEOBIA is still limited by important issues related to product evaluation and knowledge management. Indeed, it is still unclear how to assess a segmentation quality (actually considered as an ill-posed problem), although Clinton et al. (2010) proposed interesting metrics to assess GEOBIA segmentation goodness through vectorbased measures. Although the integration of knowledge expertise in the image interpretation process is a main strength of GEOBIA, it can also be considered as a main limitation as long as two experts do not share a consensual knowledge (Belgiu et al., 2014). In such a context, it is likely that knowledge representation techniques such as ontologies can play a pivotal role (Arvor et al., 2013b). This point is especially meaningful in the case of agricultural system mapping where expert knowledge is crucial and often difficult to formalize. In case of land cover products, Comber et al. (2005) investigated the semantic and ontological meanings of land cover classes and concluded that current paradigms for reporting data quality do not adequately communicate the producer's knowledge. In case of land use and land use system products, the ontological meaning of the classes is even more difficult to formalize. For example, agricultural practices such as double cropping or no-tillage have been studied in various regions of the world although they might correspond to different practices on the ground (different types of crop, different levels of soil management). In conclusion, ontologies might play an important role to allow comparison of complex and heterogeneous land maps.

\subsection{Towards an extended landscape agronomy approach}

Landscape and agronomy have long been considered as closely associated. The first references on the relationship between agricultural landscapes and field management appeared in the 1990s, (e.g., Baudry, 1993; Deffontaines et al., 1995) and addressed how farming activities produce agricultural landscapes, i.e., explained the spatial distribution of patches (fields and associated boundaries). Since then, very few studies were published on the relationship between agricultural practices and landscape properties (e.g., Galli et al., 2010; Herzog et al., 2006). 
Most of the research focused on the characterization and understanding of landscape patterns to relate them to ecological issues (e.g., Baudry, 1993; Herzog et al., 2006). Benoit et al. (2012) argued why and how agronomy can contribute to landscape research with a conceptual model. He suggested a new perspective on farming practices as a crucial driver in the landscape patternagricultural process relationship. He proposed to develop a new research area called Landscape Agronomy (see also Rizzo et al., 2013) defined as "the relations among farming practices, natural resources and landscape patterns, which are involved in the dynamics of agricultural landscapes".

We previously mentioned that few landscape studies related to agricultural issues use remote sensing. Although it is now widely understood that cropping practices adopted in agricultural systems shape rural landscapes, we believe it is time to use landscape agronomy and quantitative remote sensing sciences. Applying concepts of landscape ecology to agricultural systems monitoring and mapping is a major idea. The case studies from Bali and Mato Grosso illustrate this new trend in landscape agronomy research and show that, thanks to its ability to identify spatial land cover patterns at local (Bali) and regional (Mato-Grosso) scales, remote sensing has become an essential source of information to identify agricultural systems.

However, landscape agronomy research will have to face the same limitations as landscape research. These limitations concern the numerous sources of error or uncertainty with producing land cover / land use maps from remote sensing imagery, and on the choice of the landscape metrics which need to show a close association with the processes to be detected (Newton et al., 2009; Hurni et al., 2013). Another source of limitation is the simplistic approach of thematic mapping and the derivation of two-dimensional pattern metrics in landscape ecology (Newton et al., 2009), while remote sensing data have the potential to provide a three-dimensional characterization of landscapes and their component parts (as seen in Bali study case) and quantitative surface variables (as seen in Mali study case) that could be directly integrated in the landscape analysis. We showed through the Mali study case that the agricultural landscapes could be indirectly characterized by using a set of satellite-derived metrics (spectral, textural, temporal metrics) without going through a thematic map of the crop types. This approach is essential when the ratio between the field size and the sensor spatial resolution is low (Lresolution), meaning land use maps cannot be produced, but it can also be used in H-resolution situation.

\section{Conclusions}

It is widely recognized that accurate, updated, and spatially explicit information on cropping systems (and thus cropping intensity) is urgently needed at the global and regional scales to provide insight into the direction and magnitude of world agricultural production in terms of crop type acreage and yield (Lobell and Field, 2007), and in terms of agricultural impacts on natural environments (Galford et al., 2008) and water resources (Thenkabail et al., 2010). Additionally, information is needed locally to monitor resources, preserve cultural landscapes and for land certification (Jouve, 2006). This information is not yet included in the regional land cover datasets, and remote sensing entirely overlooks the actual practice of agriculture (what is grown, how it is grown, what inputs are used) at this scale (Monfreda et al., 2008). 
In this paper, we showed how the current generation of Earth observation systems can contribute to the characterization of agricultural systems locally and regionally, through bibliographic studies and three case studies. We showed that the remote sensing ability to describe cropping systems is mainly related to the ratio between the spatial resolution of the sensor and the size of the landscape elements. This ratio determines if the fields (or the trees) can be identified by the observation system, or if the remote sensing data offers only a view of the cropland in its environment. This latter case leads to the development of new tools and methods to indirectly connect the spatial patterns of the agricultural landscape to the cropping management practices over large territories.

This bibliographic overview shows that the research community is now at a turning point where landscape research is not devoted to ecological issues only, but has started to embrace agricultural matters also. We believe that landscape agronomy is on the right track, and that the current and future Earth observing systems (such as Sentinel-2 or Landsat8) will have an important role to play in this new research area. 


\section{References}

Adami, M., Mello, M.P., Aguiar, D.A., Rudorff, B.F.T., Souza, A.F., 2012. A Web Platform Development to Perform Thematic Accuracy Assessment of Sugarcane Mapping in SouthCentral Brazil. Remote Sensing, 4, 3201-3214.

Aksoy, S., Yalniz, I.Z., Tasdemir, K., 2012. Automatic Detection and Segmentation of Orchards Using Very High Resolution Imagery. Ieee Transactions on Geoscience and Remote Sensing, 50, 3117-3131.

Anderson, J.R., Hardy, E.E., Roach, J.T., Witmer, R.E., 1976. A Land Use And Land Cover Classification System For Use With Remote Sensor Data. United States Government Printing Office, Washington (US1, $41 \mathrm{pp}$.

Anderson, L.O., Rojas, E., Shimabukuro, Y., 2003. Avanço da soja sobre os ecossistemas cerrado e floresta no Estado do Mato Grosso. XI Simpósio Brasileiro de Sensoriamento Remoto, Belo Horizonte, Brésil, 19-25.

Anderson, W., You, L.Z., Wood, S., Wood-Sichra, U., Wu, W., 2014. A Comparative Analysis of Global Cropping Systems Models and Maps. IFPRI, Washington DC (US), 33 pp.

Arvor, D., Dubreuil, V., Ronchail, J., Simoes, M., Funatsu, B.M., 2014. Spatial patterns of rainfall regimes related to levels of double cropping agriculture systems in Mato Grosso (Brazil). International Journal of Climatology, 34, 2622-2633.

Arvor, D., Dubreuil, V., Simoes, M., Bégué, A., 2013a. Mapping and spatial analysis of the soybean agricultural frontier in Mato Grosso, Brazil, using remote sensing data. GeoJournal, $78,833-860$.

Arvor, D., Durieux, L., Andres, S., Laporte, M.A., 2013b. Advances in Geographic ObjectBased Image Analysis with ontologies: A review of main contributions and limitations from a remote sensing perspective. ISPRS Journal of Photogrammetry and Remote Sensing, 82, 125137.

Arvor, D., Jonathan, M., Meirelles, M.S.P., Dubreuil, V., Durieux, L., 2011. Classification of MODIS EVI time series for crop mapping in the state of Mato Grosso, Brazil. International Journal of Remote Sensing, 32, 7847-7871.

Arvor, D., Meirelles, M., Dubreuil, V., Begue, A., Shimabukuro, Y.E., 2012. Analyzing the agricultural transition in Mato Grosso, Brazil, using satellite-derived indices. Applied Geography, 32, 702-713.

Atzberger, C., Rembold, F., 2013. Mapping the Spatial Distribution of Winter Crops at SubPixel Level Using AVHRR NDVI Time Series and Neural Nets. Remote Sensing, 5, 13351354.

Baudry, J., 1993. Landscape dynamics and farming systems - Problems of relating patternes and predicting ecological changes. Lewis Publishers Inc, Boca Raton,

Belgiu, M., Hofer, B., Hofmann, P., 2014. Coupling formalized knowledge bases with objectbased image analysis. Remote Sensing Letters, 5, 530-538. 
Benoit, M., Rizzo, D., Marraccini, E., Moonen, A.C., Galli, M., Lardon, S., Rapey, H., Thenail, C., Bonari, E., 2012. Landscape agronomy: a new field for addressing agricultural landscape dynamics. Landscape Ecology, 27, 1385-1394.

Bisquert, M., Bégué, A., Deshayes, M., 2014. A methodology for delineating landscapes patches at the regional scale using OBIA techniques applied to MODIS time series of vegetation and texture indices. International Journal of Applied Earth Observation and Geoinformation (in press).

Blaschke, T., Hay, G.J., Kelly, M., Lang, S., Hofmann, P., Addink, E., Queiroz Feitosa, R., van der Meer, F., van der Werff, H., van Coillie, F., Tiede, D., 2014. Geographic Object-Based Image Analysis - Towards a new paradigm. ISPRS Journal of Photogrammetry and Remote Sensing, 87, 180-191.

Boschetti, L., Flasse, S.P., Brivio, P.A., 2004. Analysis of the conflict between omission and commission in low spatial resolution dichotomic thematic products: The Pareto Boundary. Remote Sensing of Environment, 91, 280-292.

Breiman, L., 2001. Random forests. Machine Learning, 45, 5-32.

Bridhikitti, A., Overcamp, T.J., 2012. Estimation of Southeast Asian rice paddy areas with different ecosystems from moderate-resolution satellite imagery. Agriculture Ecosystems \& Environment, 146, 113-120.

Brown, J.C., Kastens, J.H., Coutinho, A.C., Victoria, D.D., Bishop, C.R., 2013. Classifying multiyear agricultural land use data from Mato Grosso using time-series MODIS vegetation index data. Remote Sensing of Environment, 130, 39-50.

Burley, T.M., 1961. Land use or land utilization? The Professionnal Geographer, 13, 18-20.

Clinton, N., Holt, A., Scraborough, J., Yan, L., Gong, P., 2010. Accuracy Assessment Measures for Object-based Image Segmentation Goodness. Photogrammetric Engineering and Remote Sensing, 76, 289-299.

Colson, F., Bogaert, J., Ceulemans, R., 2011. Fragmentation in the Legal Amazon, Brazil: Can landscape metrics indicate agricultural policy differences? Ecological Indicators, 11, 14671471.

Coltri, P.P., Zullo, J., Goncalves, R.R.D., Romani, L.A.S., Pinto, H.S., 2013. Coffee Crop's Biomass and Carbon Stock Estimation With Usage of High Resolution Satellites Images. Ieee Journal of Selected Topics in Applied Earth Observations and Remote Sensing, 6, 1786-1795.

Comber, A.J., Fisher, P.F., Wadsworth, R.A., 2005. You know what land cover is but does anyone else?...an investigation into semantic and ontological confusion. International Journal of Remote Sensing, 26, 223-228.

Congalton, R.G., Green, K., 1999. Assessing the Accuracy of Remotely Sensed Data: Principles and Practices. Boca Raton, Florida, 137 p.

Deffontaines, J.P., Thenail, C., Baudry, J., 1995. Agricultural systems and landscape patterns How can we build a relationship ? Landscape and Urban Planning, 31, 3-10. 
DeFries, R., Rosenzweig, C., 2010. Toward a whole-landscape approach for sustainable land use in the tropics. Proceedings of the National Academy of Sciences of the United States of America, 107, 19627-19632.

Dixon, J., Gulliver, A., Gibbon, D., 2001. Farming Systems and Poverty: Improving farmers' livehoods in a changing world. FAO and World Bank, Rome and Washington D.C.

FAO, 2011. Looking ahead in world food and agriculture: Perspectives to 2050. FAO, Rome (IT), $539 \mathrm{p}$.

Florinsky, I.V., 1998. Combined analysis of digital terrain models and remotely sensed data in landscape investigations. Progress in Physical Geography, 22, 33-60.

Fox, J., Kanter, R., Yarnasarn, S., Ekasingh, M., Jones, R., 1994. Farmer decision-making and spatial variables in northern Thailand. Environmental Management, 18, 391-399.

Fu, R., Yin, L., Li, W.H., Arias, P.A., Dickinson, R.E., Huang, L., Chakraborty, S., Fernandes, K., Liebmann, B., Fisher, R., Myneni, R.B., 2013. Increased dry-season length over southern Amazonia in recent decades and its implication for future climate projection. Proceedings of the National Academy of Sciences of the United States of America, 110, 18110-18115.

Galford, G.L., Mustard, J.F., Melillo, J., Gendrin, A., Cerri, C.C., Cerri, C.E.P., 2008. Wavelet analysis of MODIS time series to detect expansion and intensification of row-crop agriculture in Brazil. Remote Sensing of Environment, 112, 576-587.

Galli, M., Bonari, E., Marraccini, E., Debolini, M., 2010. Characterisation of agri-landscape systems at a regional level: A case study in northern tuscany. Italian Journal of Agronomy, 5, 285-294.

Gobin, A., Campling, P., Deckers, J., Feyen, J., 2001. Integrated land resources analysis with an application to Ikem (south-eastern Nigeria). Landscape and Urban Planning, 52, 95-109.

Guillen-Climent, M.L., Zarco-Tejada, P.J., Villalobos, F.J., 2014. Estimating Radiation Interception in Heterogeneous Orchards Using High Spatial Resolution Airborne Imagery. IEEE Geoscience and Remote Sensing Letters, 11, 579-583.

Hay, G.J., Castilla, G., 2008. Geographic object-based image analysis (GEOBIA): a new name for a new discipline In: Blaschke, T., Lang, S., Hay, G.J. (Ed.), Object-Based Image Analysis, Springer Berlin Heidelberg, 75-89.

Hay, G.J., Marceau, D., Dube, P., Bouchard, A., 2001. A multiscale framework for landscape analysis: Object-specific analysis and upscaling. Landscape Ecology, 16, 471-490.

Herzog, F., Steiner, B., Bailey, D., Baudry, J., Billeter, R., Bukácek, R., De Blust, G., De Cock, R., Dirksen, J., Dormann, C.F., De Filippi, R., Frossard, E., Liira, J., Schmidt, T., Stöckli, R., Thenail, C., van Wingerden, W., Bugter, R., 2006. Assessing the intensity of temperate European agriculture at the landscape scale. European Journal of Agronomy, 24, 165-181.

Hurni, K., Hett, C., Epprecht, M., Messerli, P., Heinimann, A., 2013. A Texture-Based Land Cover Classification for the Delineation of a Shifting Cultivation Landscape in the Lao PDR Using Landscape Metrics. Remote Sensing, 5, 3377-3396. 
Hutchinson, C.F., 1991. Uses of satellite data for famine early warning in sub-Saharan Africa. International Journal of Remote Sensing, 12, 1405-1421.

Jasinski, E., Morton, D., DeFries, R., Shimabukuro, Y., Anderson, L., Hansen, M., 2005. Physical landscape correlates of the expansion of mechanized agriculture in Mato Grosso, Brazil. Earth Interactions, 9.

Jouve, P., 2006. Cropping systems and farming land space organisation: A comparison between temperate and tropical farming systems. Cahiers Agricultures, 15, 255-260.

Korting, T.S., Fonseca, L.M.G., Camara, G., 2013. GeoDMA-Geographic Data Mining Analyst. Computers \& Geosciences, 57, 133-145.

Koschke, L., Fürst, C., Lorenz, M., Witt, A., Frank, S., Makeschin, F., 2013. The integration of crop rotation and tillage practices in the assessment of ecosystem services provision at the regional scale. Ecological Indicators, 32, 157-171.

Kuemmerle, T., Erb, K., Meyfroidt, P., Muller, D., Verburg, P.H., Estel, S., Haberl, H., Hostert, P., Jepsen, M.R., Kastner, T., Levers, C., Lindner, M., Plutzar, C., Verkerk, P.J., van der Zanden, E.H., Reenberg, A., 2013. Challenges and opportunities in mapping land use intensity gIobally. Current Opinion in Environmental Sustainability, 5, 484-493.

Kunwar, P.K., T. S. ; Kumar, A. ; Agrawal, A. K. ; Singh, A. N.; Mendiratta, N.,, 2010. Use of high-resolution IKONOS data and GIS technique for transformation of landuse/landcover for sustainable development. Current Science, 98, 204-212.

Lambin, E.F., Geist, H.J., Rindfass, R.R., 2006. Introduction: local processes with global impacts. In: Lambin, E.F., Geist, H.J. (Eds.), Land-use and land-cover change: local processes and global impacts. Springer-Verlag, Berlin, Heidelberg, 1-8.

Leenhardt, D., Angevin, F., Biarnes, A., Colbach, N., Mignolet, C., 2010. Describing and locating cropping systems on a regional scale. A review. Agronomy for Sustainable Development, 30, 131-138.

Lei, Z., Bingfang, W., Liang, Z., Peng, W., 2012. Patterns and driving forces of cropland changes in the Three Gorges Area, China. Regional Environmental Change, 12, 765-776.

Lobell, D.B., Field, C.B., 2007. Global scale climate - crop yield relationships and the impacts of recent warming. Environmental Research Letters, 2:014002, 7 pp.

Marceau, D.J., Howarth, P.J., Gratton, D.J., 1994. Remote-sening and the measurement of geographical entities in a forested environment. 1. The scale and spatial aggregation problem. Remote Sensing of Environment, 49, 93-104.

McGarigal, K., 2014. FRAGSTATS: Spatial Pattern Analysis Program for Categorical Maps Documentation.

Monfreda, C., Ramankutty, N., Foley, J.A., 2008. Farming the planet: 2. Geographic distribution of crop areas, yields, physiological types, and net primary production in the year 2000. Global Biogeochemical Cycles, 22. 
Montagnon, C., 2006. Coffee: Terroirs and quality. Cemagref/INRA/CIRAD, Versailles, France,

Morton, D., DeFries, R., Shimabukuro, Y., Anderson, L., Arai, E., del Bon Espirito-Santo, F., Freitas, R., Morisette, J., 2006. Cropland expansion changes deforestation dynamics in the southern Brazilian Amazon. Proceedings of the National Academy of Sciences of the United States of America, 103, 14637-14641.

Mougel, B., Lelong, C., 2008. Classification and information extraction in very high resolution satellite images for tree crops monitoring. 28th EARSel Symposium Remote Sensing for a Changing Europe, Istambul, 13 pages.

Newton, A.C., Hill, R.A., Echeverria, C., Golicher, D., Benayas, J.M.R., Cayuela, L., Hinsley, S.A., 2009. Remote sensing and the future of landscape ecology. Progress in Physical Geography, 33, 528-546.

Ozdogan, M., 2010. The spatial distribution of crop types from MODIS data: Temporal unmixing using Independent Component Analysis. Remote Sensing of Environment, 114, 1190-1204.

Panigrahy, S., Manjunath, K.R., Ray, S.S., 2005. Deriving cropping system performance indices using remote sensing data and GIS. International Journal of Remote Sensing, 26, 25952606.

Panigrahy, S., Ray, S.S., Manjunath, K.R., Pandey, P.S., Sharma, S.K., Sood, A., Yadav, M., Gupta, P.C., Kundu, N., Parihar, J.S., 2011. A Spatial Database of Cropping System and its Characteristics to Aid Climate Change Impact Assessment Studies. Journal of the Indian Society of Remote Sensing, 39, 355-364.

Peña-Barragán, J.M., Jurado-Expósito, M., López-Granados, F., Atenciano, S., Sánchez-de la Orden, M., Garcia-Ferrer, A., Garcia-Torres, L., 2004. Assessing land-use in olive groves from aerial photographs. Agriculture, Ecosystems and Environment, 103, 117-122.

Plexida, S.G., Sfougaris, A.I., Ispikoudis, I.P., Papanastasis, V.P., 2014. Selecting landscape metrics as indicators of spatial heterogeneity-A comparison among Greek landscapes. International Journal of Applied Earth Observation and Geoinformation, 26, 26-35.

Pocas, I., Cunha, M., Pereira, L.S., 2011. Remote sensing based indicators of changes in a mountain rural landscape of Northeast Portugal. Applied Geography, 31, 871-880.

Pontius, R.G., Millones, M., 2011. Death to Kappa: birth of quantity disagreement and allocation disagreement for accuracy assessment. International Journal of Remote Sensing, 32, 4407-4429.

Rizzo, D., Marraccini, E., Lardon, S., Rapey, H., Debolini, M., Benoit, M., Thenail, C., 2013. Farming systems designing landscapes: land management units at the interface between agronomy and geography. Geografisk Tidsskrift-Danish Journal of Geography, 113, 71-86.

Soumare, M., 2008. Dynamique et Durabilité des Systemes Agraires à Base de Coton au Mali. Université de Paris X Nanterre (FR), Paris (France), 373 p. 
Strahler, A.H., Woodcock, C.E., Smith, J.A., 1986. On the nature of models in remote sensing. Remote Sensing of Environment, 20, 121-139.

Thenkabail, P., Lyon, G.J. , Turral, H., Biradar, C.M., 2009. Remote Sensing of Global Croplands for Food Security. . CRC Press, Taylor and Francis group, Boca Raton, London, New York,

Thenkabail, P.S., Hanjra, M.A., Dheeravath, V., Gumma, M., 2010. A Holistic View of Global Croplands and Their Water Use for Ensuring Global Food Security in the 21st Century through Advanced Remote Sensing and Non-remote Sensing Approaches. Remote Sensing, 2, 211-261.

UN, 2010. World Population Prospects, the 2010 Revision. United Nations, Department of Economic and Social Affairs, Population Division, New York (USA), ST/ESA/SER.A/307; Sales No. E.11.XIII.6.

Ursani, A.A., Kpalma, K., Lelong, C.C.D., Ronsin, J., 2012. Fusion of Textural and Spectral Information for Tree Crop and Other Agricultural Cover Mapping With Very-High Resolution Satellite Images. Ieee Journal of Selected Topics in Applied Earth Observations and Remote Sensing, 5, 225-235.

USAID, 2009. Application of the Livelihood Zone Maps and Profiles for Food Security Analysis and Early Warning - Guidance for Famine Early Warning Systems Network (FEWS NET) Representatives and Partners. USAID, pp. 23.

Uuemaa, E., Mander, Ü., Marja, R., 2013. Trends in the use of landscape spatial metrics as landscape indicators: A review. Ecological Indicators, 28, 100-106.

Vaclavik, T., Lautenbach, S., Kuemmerle, T., Seppelt, R., 2013. Mapping global land system archetypes. Global Environmental Change, 23, 1637-1647.

Verburg, P.H., Mertz, O., Erb, K.-H., Haberl, H., Wu, W., 2013. Land system change and food security: towards multi-scale land system solutions. Current Opinion in Environmental Sustainability, 5, 494-502.

Verburg, P.H., van de Steeg, J., Veldkamp, A., Willemen, L., 2009. From land cover change to land function dynamics: A major challenge to improve land characterization. Journal of Environmental Management, 90, 1327-1335.

Vintrou, E., Begue, A., Baron, C., Saad, A., Lo Seen, D., Traore, S.B., 2014. A Comparative Study on Satellite- and Model-Based Crop Phenology in West Africa. Remote Sensing, 6, 13671389 .

Vintrou, E., Desbrosse, A., Begue, A., Traore, S., Baron, C., Lo Seen, D., 2011. Crop area mapping in West Africa using landscape stratification of MODIS time series and comparison with existing global land products. International Journal of Applied Earth Observation and Geoinformation, 14, 83-93.

Vintrou, E., Ienco, D., Begue, A., Teisseire, M., 2013. Data Mining, A Promising Tool for Large-Area Cropland Mapping. Ieee Journal of Selected Topics in Applied Earth Observations and Remote Sensing, 6, 2132-2138. 
Vintrou, E., Soumare, M., Bernard, S., Begue, A., Baron, C., Lo Seen, D., 2012. Mapping Fragmented Agricultural Systems in the Sudano-Sahelian Environments of Africa Using Random Forest and Ensemble Metrics of Coarse Resolution MODIS Imagery. Photogrammetric Engineering and Remote Sensing, 78, 839-848.

Wästfelt, A., Tegenu, T., Nielsen, M.M., Malmberg, B., 2012. Qualitative satellite image analysis: Mapping spatial distribution of farming types in Ethiopia. Applied Geography, 32, 465-476.

Wintgens, J.-N., 2004. Factors influencing the quality of green coffee. In: Wintgens, J.-N. (Ed.), Coffee: Growing, processing, sustainable production: a guidebook for growers, processors, traders, and researchers, Weihnheim, Germany, 789-809.

You, L.Z., Wood, S., 2006. An entropy approach to spatial disaggregation of agricultural production. Agricultural Systems, 90, 329-347.

You, L.Z., Wood, S., Wood-Sichra, U., 2009. Generating plausible crop distribution maps for Sub-Saharan Africa using a spatially disaggregated data fusion and optimization approach. Agricultural Systems, 99, 126-140. 